Portland State University

PDXScholar

1973

\title{
Family variables which are associated with achievement of community tenure by persons released from psychiatric hospitalization
}

Thomas Mack Chambers

Portland State University

Follow this and additional works at: https://pdxscholar.library.pdx.edu/open_access_etds

Part of the Other Mental and Social Health Commons, Psychoanalysis and Psychotherapy Commons, and the Social Work Commons

Let us know how access to this document benefits you.

\section{Recommended Citation}

Chambers, Thomas Mack, "Family variables which are associated with achievement of community tenure by persons released from psychiatric hospitalization" (1973). Dissertations and Theses. Paper 1656. https://doi.org/10.15760/etd.1655

This Thesis is brought to you for free and open access. It has been accepted for inclusion in Dissertations and Theses by an authorized administrator of PDXScholar. Please contact us if we can make this document more accessible: pdxscholar@pdx.edu. 
AN ABSTRACT OF THE THESIS OF Thomas Mack Chambers for the Master of Social Work presented May 16, 1973.

Title: Family Variabies Which Are Associated with the Achievement of Community Tenure by Persons Released from Psychiatric Hospitalization.

APPROVED BY MEMBERS OF THE THESIS COMMITTEE:

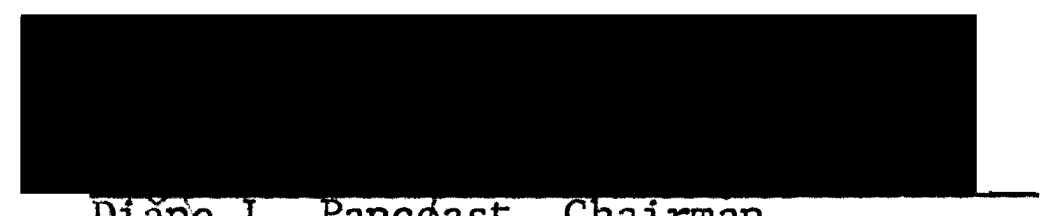

Diăne L. Pancoast, Chairman

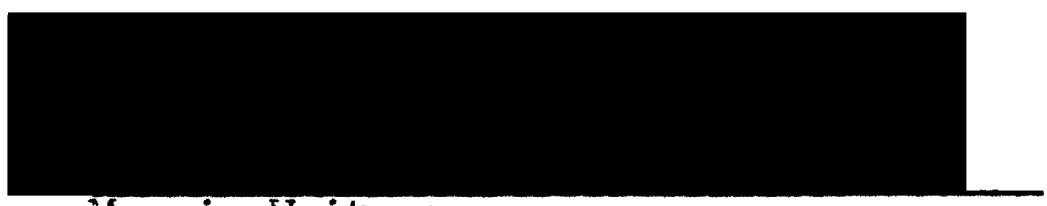

Morris Weitman

The pattern of frequent discharges and readmissions which characterizes most psychiatric hospitalization in this country today was described, and it was argued that the costs of this "revolving door" outweigh such benefits as might be derived from it. An alternative stepwise progression model of aftercare was proposed. This model identified community tenure as the most appropriate goal for initial aftercare efforts.

Attempts to identify correlates of the establishment 
of community tenure by mental hospital releasees were reviewed. It was found that the ex-patient's abiitty to remain in the comrnunity is not highly correlated with the extent to which he manifests deviant behavior. This finding was interpreted as an indication that environmental factors may play a significant part in ex-patients' avuidance of rehospitalization.

Data were presented which indicated that a clear majority of mental hospital releasees take up residency immediately with family members. It was hypothesized, then, that measurable family variables are correlated with the ability of the ex-patient to achieve community tenure.

An attempt was made to examine this hypothesis in the light of relevant research. Studies of the issue which contained substantive empirical support were categorized into four topic areas: family tolerance of the ex-patient's symptomatic behavior, kin role which the family affords to the ex-patient, familial expectations of the ex-patient's performance, and family attitudes and personality characteristics.

After reviewing the studies of authors who attempted to assess the degree of correlation between the capacity of the ex-patient's family to tolerate symptomatic behavior on the part of the ex-patient and the exr-patient's ability to avoid rehospitalization, it was concluded that the linear correlation between the two variables which would be predicted logically may not exist. 
A review of studies of the relationship between the kin role which the ex-patient's family affords to him and the ex-patient's ability to achieve comnunity tenure yielded a tentative conclusion that returning to the socialbiological role of "child" (son or daughter) as opposed to the kin role of spouse was positively correlated with remaining in the community.

After examining studies which attempted to explore the relationship between familial expectations of instrumental performance on the part of the ex-patient and the ability of the ex-patient to avoid rehospitalization, it was concluded that little support was provided for the hypothesis that the two variables are related.

A survey of attempts to identify family attitude and personality characteristic correlates of ex-patient achievement of community tenure resulted in arrival at the conclusion that such efforts, as a whole, have met with little success, although significant correlations between two general family attitudes toward mental illness and ex-patient avoidance of rehospitalization were found.

Considering the findings which were reviewed as a whole, it was concluded that little support was provided for the hypothesis that measurable family variables are correlated with the ability of the ex-patient to achieve conmunity tenure. The rather limited aftercare practice applications which could be drawn from the few correlations that have been dis- 
covered were described, and implications of the over-aIl finding for future research were discussed. 
FAMTIY VARTABLES WHICH ARE ASSOCIATED WITI

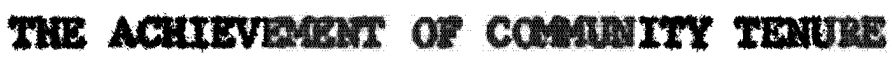

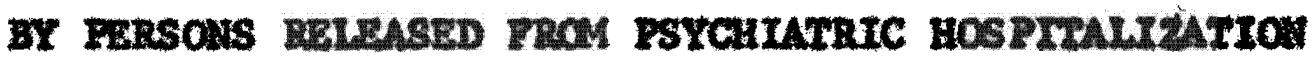

by

A theels abmitted in pextial fulfillmont of the requit remente for the dogree of

MASTER of socul. woxk

PORTLAND SWATE UAIVaRS ITY

1973 
TO THE OFFICE OF GRADUATE STUDIES AND RESEARCH: The nombers of the Committee approve the thesis of Thonas Mack Chambers presented May 16, 1973.

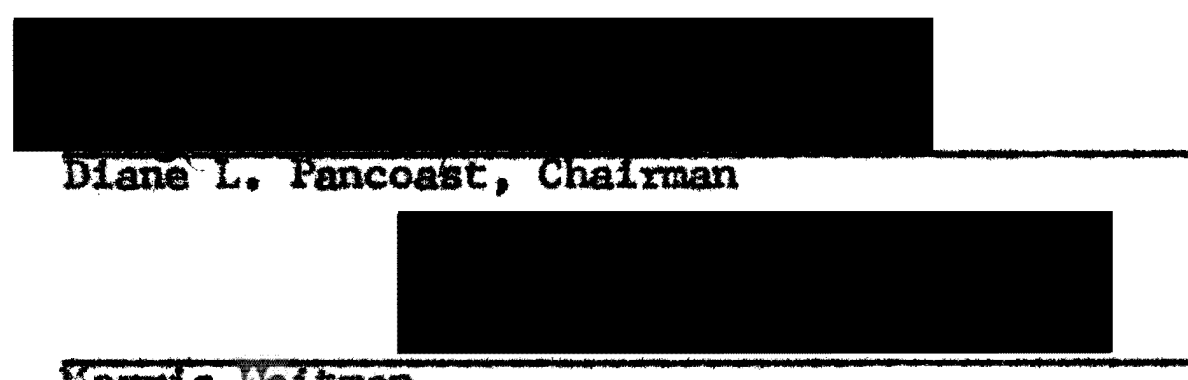
Morris Weitman

APPROVED:

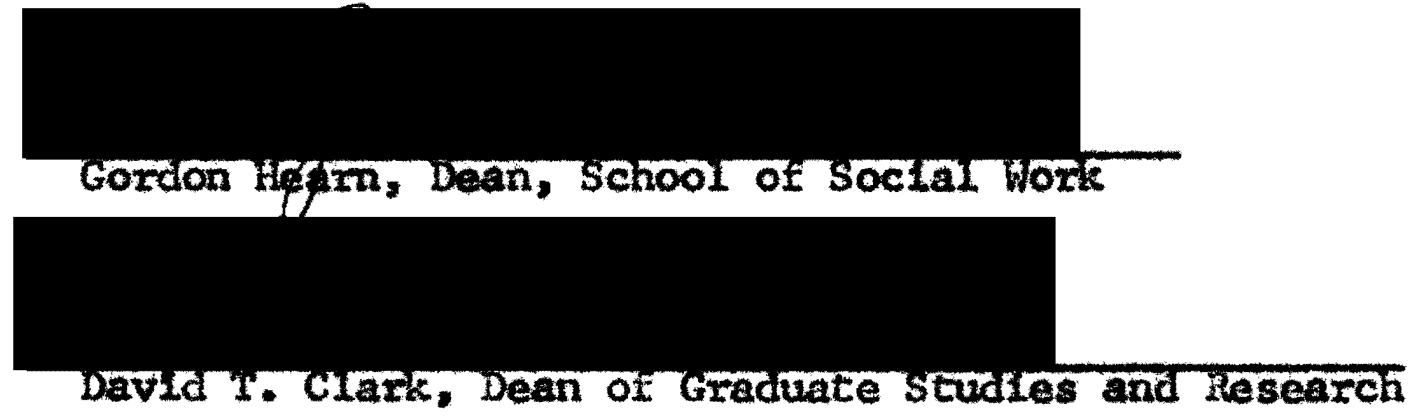

May 16, 1973 


\section{ACCNOWLDGMETS}

I would like to entend ay alneerset thmoles to Ma. DLang Paneonet of the School of SocLal Woxk and Dr. Morrts Weltman of the Department of Raychology for thatr invaluable assietance in this affort.

$$
\text { T.C. }
$$


TABLs of cosrrats

PACE

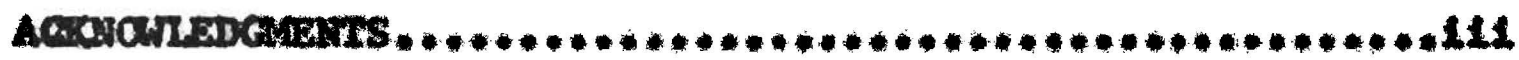

eratan

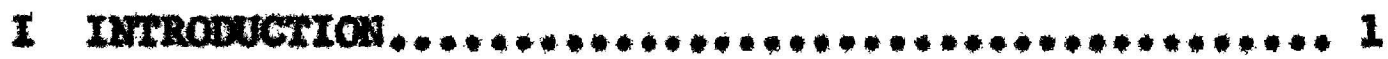

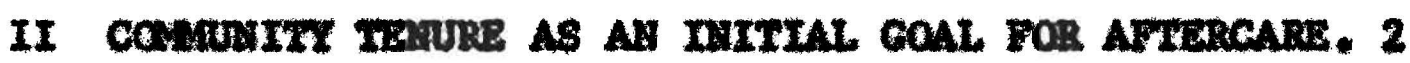

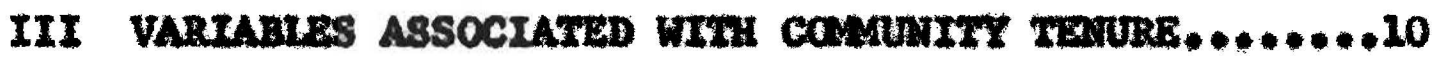

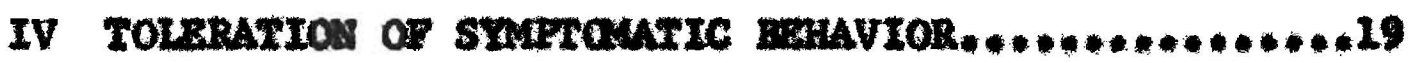

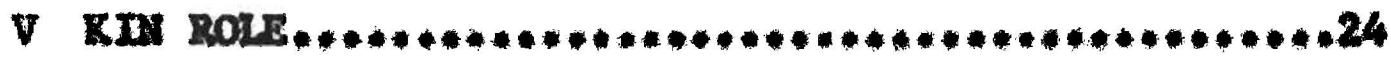

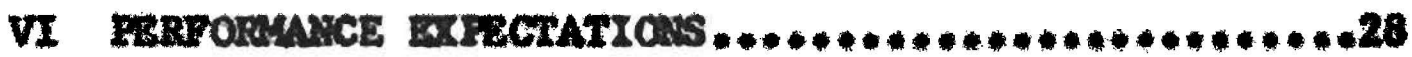

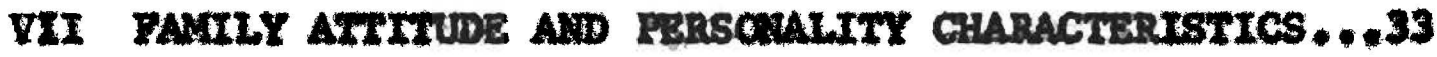

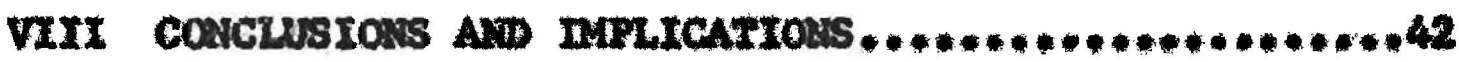

Sumany .............................................42

Conclunlone....................................,49

Implicatlons for Practice.........................50

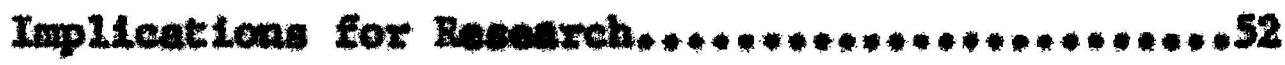

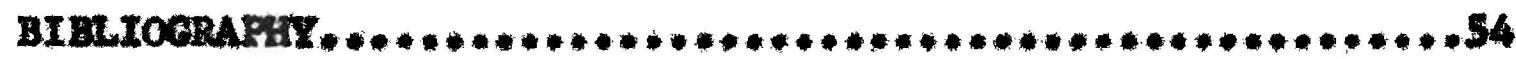


CHAPTER I

\section{INTRODUCTION}

The cyclical process of raptd discharges and frequent readmiseloas which characteriess most psyehlatric hospitaI1zation in the Untted States todey has been well docturented. S11vertstin, In a study of all of the persons raleased fxom psychiatric hospltalieation in the state of prenneylvanta during a givan calandax year, found that 25,76 of those persons ware readmitted during the following one year partod (1, p.26). Michare te al. found that 37,4\% of the releasees from state hoapttals in Maxylend whom they studied returned to those hooptitals duxtng the year which followed thalx diacharge $(2, p * 68)$. Frenen and Stmmons. In a study of all perrens ditcharged from twelve wate pwychlatric bospitals in eastern Manswchusetts durIng a given six moath pertod, found a retuxn wate of $38,2 \%$ chring the following year. (3, p,43). Mlllex reports that $72 \%$ of those persons released on "leave of absence" atatus fron state mental bospitals into the Oukland, Callfornta awe during a given yeur were reboaptallad during the absequent six yeax period (4, p.24). The paychological and social coses of this "revolving door" process have also been discusted at sone length. 
Michaux ot al.. for exhmple, have dlseusged the edverse pay" chalogical effect on the patient of Hifing altemantively in two worlds, all the whlle wth an inpalred senes of belong* ing in elther" (2, p, 153). Freamen and sinmons" discuestion of the negative congequences of this process for the patient's signiflcant others and for the commentty at laxg $(3, p, 2-3)$ exerpliftes efforts to describe varlous aspecte of the resultent soctal detriment.

Certain authors, hovever, defiend this process. Some

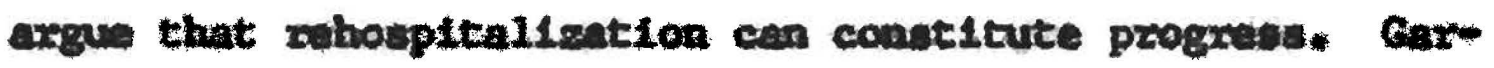
nex (5). For exnmple, argues that rehospitalization is

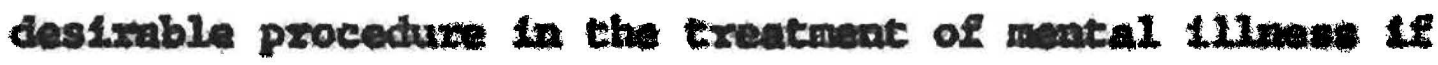
mental 111 ness is viewed as a devtunt behavlor rather than a diente. Similarly, Brom ergues that periodte readmin:olon 28 an effective wy of arolding some of the distxass whlch is assoctated with resurring symptomatology (6, p. 12), and Lina describes pertodic readalosion fxequently being a necesary paxt of the process of "stablulying the definttive stage of enotlonal sestoration" (7, p,18) * Othor authors, such as Braglnsky at at. (8), defead the procedure by aspexting that mental hoopitals should serve as refuges,

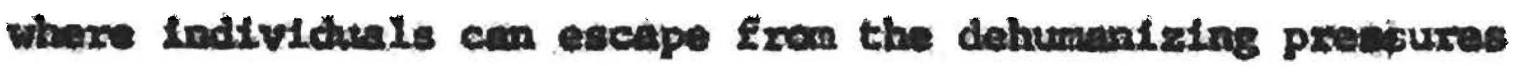
of soctety whenever they neud to do so, regardless of hou often particular individuals night make wse of this service. The preponderance of opinton among mental health pro* fensionals in this country, hovever, supports interxupting 
this pettern, as is Indicated by mancous and extencive nesewroh efforte which are Alreted at Ldentifying vaxtables whoh ax aspoctated with the expotient ramaining in the comenutty (e.8, 2, 3, 4, 9). Many mental bedth theoriate

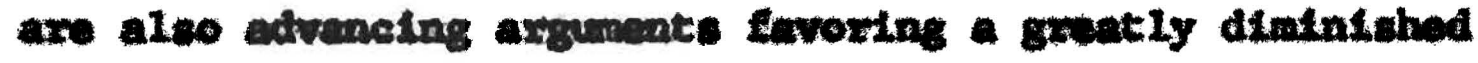
wole for poychtatric boopital caxe in seneral (ef., 10, 11). Angrigt et al. capturs the tenor of the argumente agalnot contlmalng to operute "the wwolving loox which have been put forth with the phrase: the matal houpltal bas yet to prove Itu accoptubility efthex a trentent center or as

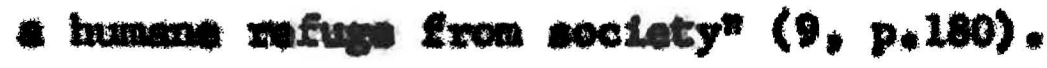

thene axpunente hold constedxble watht, paxtieum laxty in view of the nugative prychological and soctel conenqunces of parlodic suboupltalletelon which have been

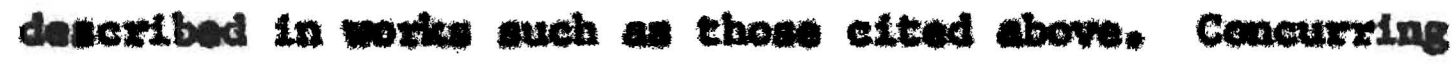
with thing authoss with rogand to the inacesptebility of periodic whoupltallection as a datrable pattexn of sem

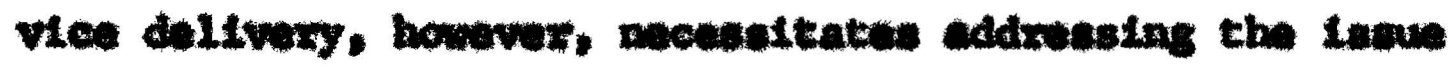

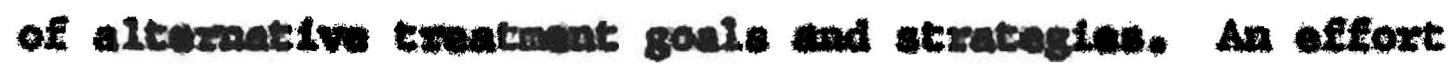

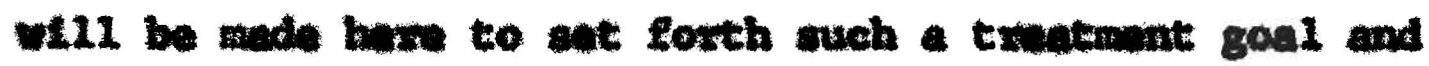
to exmine entain factors wich my be ansoctated with $1 t$. 
Gapar II

COAMNIT TEMURE AS AI IAITIAL GOAL FOR ATHERCARE

If a Iffe-style which involves portodic mehospitaliation is not accoptable as a tzatunt gonl, then the log" 1cal altenative is rempining in the commates with no wehoupitelisation. Bom authors argua, bowwex, that cxuma" Ity temure is not enough. Thes cuthors sed sow committy settinge so not being appreclably differmt fxon mated hospttals with regand to the 1ife-atyle which is afforded to the restdents, Lemb and Guertese 1, for cumple, deactibe cextaln boarding homes an "not really in the commentty"

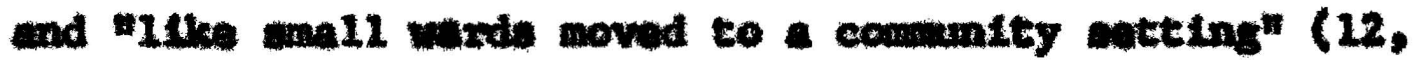
p.30). Thexelow, thee enthore arget that some foxm of Ingtranental parformance" as daftned by work or soctal paxtletpation, sheuld be adopted as the primaxy goal of aftencane. Freunan and Simmons underseowe buch an axgument with sefoxence to th commulty tenured but soctally and oecupationally inect Iv expettent as aseleas con" suating unit" who "diverte ocher ccamualty mabers to wasteful takk" (3, p.38).

Otbax authors view cosmuntty maintenance at any Iovel of performance a being decidediy preforable to inotitu-

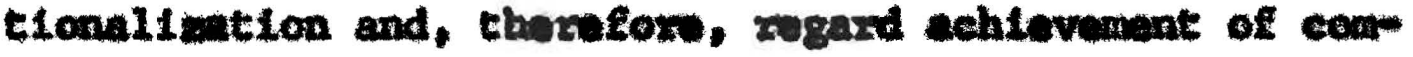


munity tenume, per wo, not only as a legitimste thexapeutice gon1, but, aleo, as the most profltuble ame of intelal focus at his time. Miller, for axmple, describes ahtevement of commulty tenure by the exmpatient as hie suceessful entgxation from a "patientworld" Into a "pexwon-world" and vime succeseful complotion of this transition as the primary goal of afterwene (4, p,1-8).

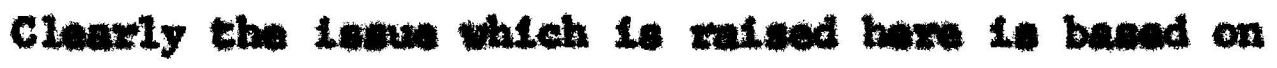
value judgement, and canaot be weolved by empixicel teutIng. Eepirteal wosenth bas Indicated, howver, that the two variablot my not be indapondent. A cenetelenuble num. ber of atudies hav found a posttive correlation betwen

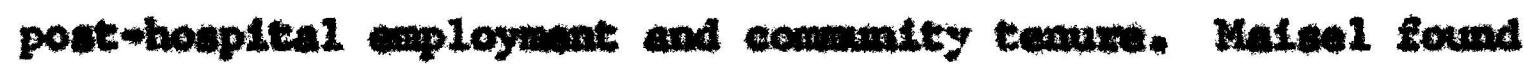

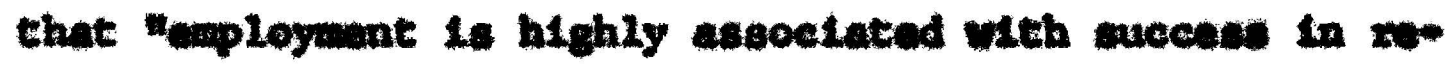

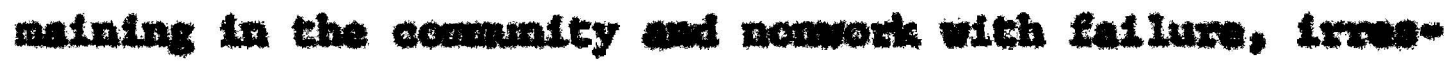
pective of ratings of eymptcantic bhavior" (13, p.22). Coldbers xoported that "those wo wowked in jobs requlIng a modexate degres of skill cuxvived boot in the com mantty" (14, P,484). Kris (15) found that poxwons who wex fully oolf-supporting wore rehouptealled leas often than those who contributed only partially or not at all to thet: an finencial support. Brow (16) Lound atgatelcent negative correlation butween the nount of time apent at woxk during the first your after discharge and whospitallevtion (16, p.119) * Frowen and simmons found ag* afficent difformens between the woxk wecordis of expoutients 
who remained in the courrumity and those tho were rehorpita11zed, although thwy reported "censiderable overiap" butwen the woxk records of the two groups $(3, \mathrm{p}, 49-50)$, and Lim (7) repoxted that the post-hospital woxk recoxds of a group of patients who was rendafted within a year after their

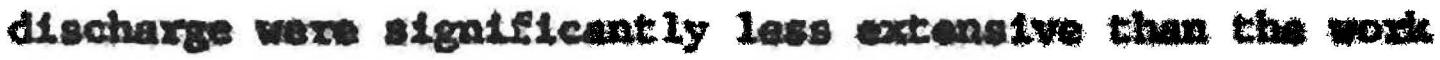

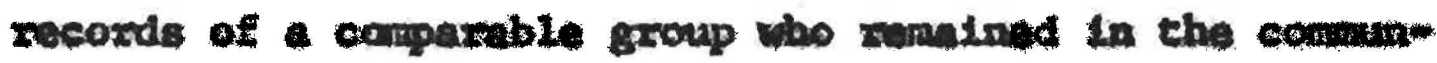
Ity for one yeur after their discharge bat wene readnitted after that.

Othiz authors have found no algniflcant correlation between employment and commmity temuso, Axthur et al. (17) foumd no relationship betwean woxk performance and anccess In establishing commintty tenuse. Gevarta and ind (18) reported that none of the various indices of econonic perm formance whlch thay studied was releted to rehoppltallaption.

Certain authors elso bave attempted to test the hy pothesis that social participation is postelvaly corwelated wth conmundty tenum, One meh study offemed support for this hypothesis. Rowen ot al, (19) found that the "soclal competence" of ex-patients ms positively comalated wth both incidence and frequency of rehospttalleatien. Othex resatrchers, however, have found no coxrelation. Arthur et al. (II) reported that "social contact" was not sigaificantly correlated with the achievement of camamity temure by ex-patients. Sinilarly, Angriat et al. (20) 
found that female ex-patients who were successful in reestabllshing themselves in the community ald not differ significantly from a comparable group of returnees with regard to soclal participation. Wessler and Kaha, in a small sample study $(N=24)$, reported that "soctal ad fustment per was not related to the patient's ablilty to remain out of the hospita1" $(21, p, 458)$. Also, Levine et a1. (22) found that measures of the ex-patient partieipation immediately after discharge were not veeful in predicting rehospitallzation.

Taken as a wole, these studies indicate that inetrumental performance in the form of amployment is positively correlated with community tenure but that periormence as measured by soclal participation is unreleted to rehospitalization. The apparent correlation between enployment and commity tenure thould be interpreted with extrention, however; ss only one of the studies elted controllad the vartable of aymptomatic behavior. The apparent correlation between employment and community ternume could be spurtous in that degree of employment could be correlated highly with lack of symptomatic behavior. Even If this factor were controlled, however, these studies would not support the contention that enployment facilitates cormanity tenure, Baployment might be a manifestation of certain basic aduptational ski1ls, for example, and those skills rather than enployment per se, might be 
directly correlated with coumenity temume.

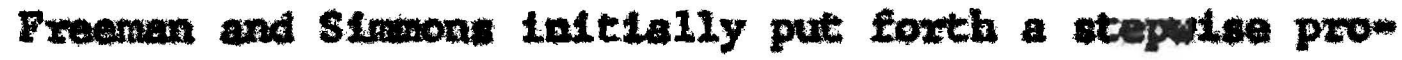
gxession model of payehtatric tehablittation $(3, p, 37)$. In terms of this mode1, communty tenume was seen as an essential first step toward full rehabilitation. The authors postulated that achlevement of this first atage goul would ald the exppatient in his achievemant of a furthar second stage goal, which they sav as instrumentel performance. Subsequent research by these authoxs, which indicated that thaw was aegligible amount of coxraletion between the two, convinced them to abobdon this model. In dolne so, they reasoned thet the fact that establishing coomumity teaure wes probably not assoclated with increasing instrumental performance precluded viewing it as an effective first step tomaxi auch performance.

However, other findings whlch axe ctted above ouggent that Freenen and Stmons may have been premature in dismissing the possibility of such a correlation, although the correlation between employment and committy tenume hich has been denonstrated could be merely a menifestation of a more basle relationship between rahospitalization and other vertables, Even if no such correlation exists, hovever, a stepwise model such as that proposed and abondonded by Freeman and Simnons would sean to have utility. Although cam munity tenure may not be sufflcient, in itwelf, to facliltate instrumental pexformmce in the commity. It is cleariy 
a mecesury procondition for such performance.

Th: puattonable natuxe of the mintelonship betwem ecm multy temus and Instrumental performances as defined at this polnt, militeces against adopting ingtwanental paxtox-

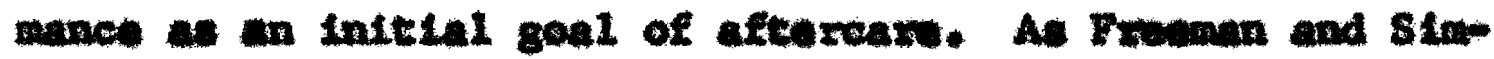
wons demonetrate (3, $\mathrm{p}, 49)$, a considerable muber of pa-

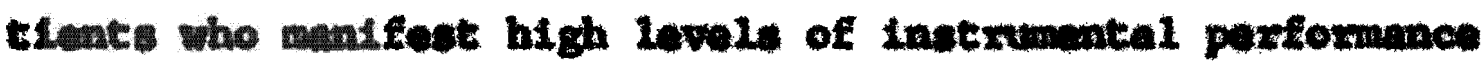
axe rehospitalland, novertholeve, It would sevm that cen" mmity tenux would be a mos prudent initial goel and that Inotrumatel paxtommen, eceoxdins to watever definttion, could be viemed profteably a delrable secondaxy gonl.

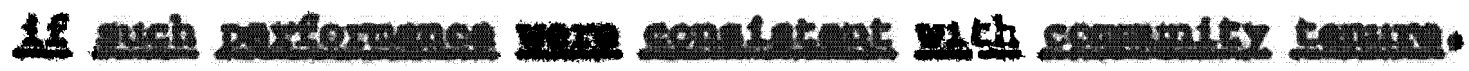


CHAFTER III

VARTABIBS ASSOCIATED WTTH CONUNTTY TIAUURE

If ecumintey temux is adopted as an Initial goal of

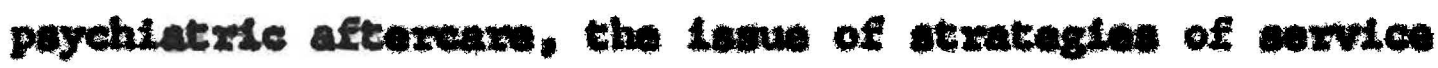
delivexy axies. Developing soxvioe dellvey stratugles which axe effective with megaxd to xuducting the incldence

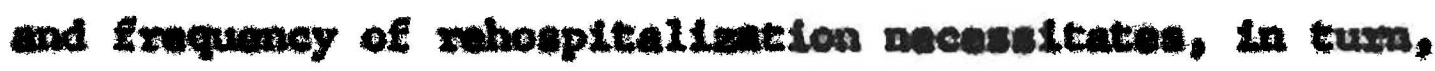
a careful craluntion of the tactors which ane lanoma to be astocleted with rehoupitaliettion.

Many aithow who argue in fevor of purtodic whouptea-

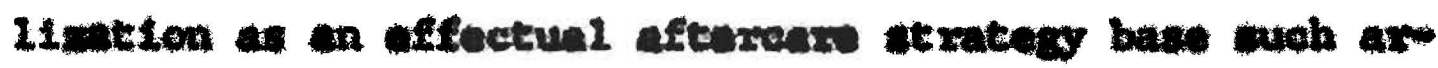

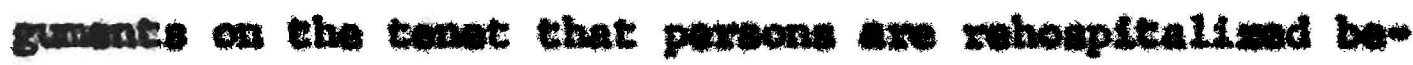

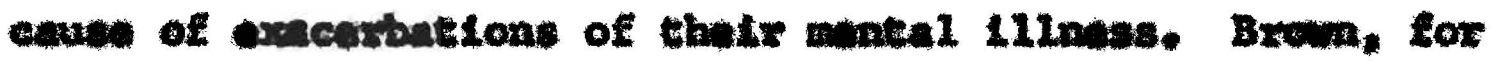

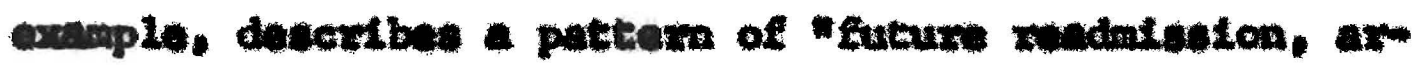
ruped by committy services, as soon as the potient begins

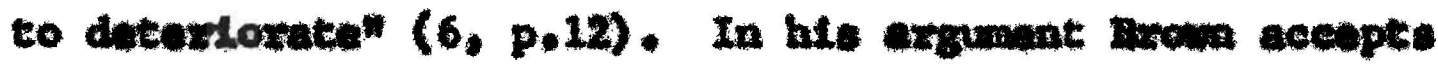

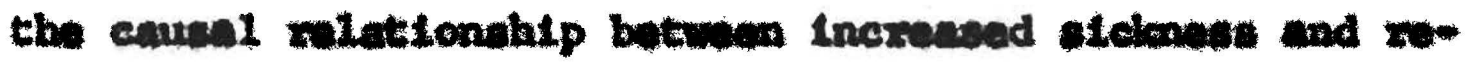

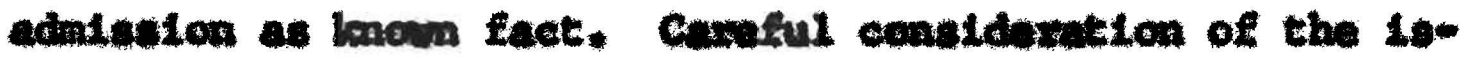

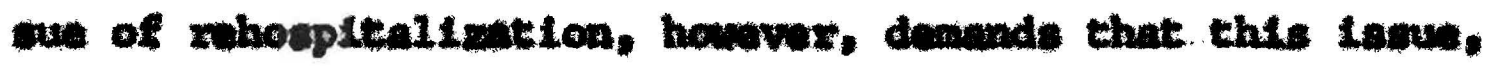
too, be namined.

Such an entmination mut begh with a cleax desextption of the two vartables. Rendmiantion can be defined in toms of apectfle adniniatrative procedures. Numonous dell- 
aftione of mentel 111nase heve been put forth (af, 23, p.9-34). Central to wot weh dafinitlons, howver, to the concept of deviant behnvior. If devient behavior to ack capted as in Integxal part of montal 121mese, then the question of the mintionshlp between mentel 111 ness and suhos-

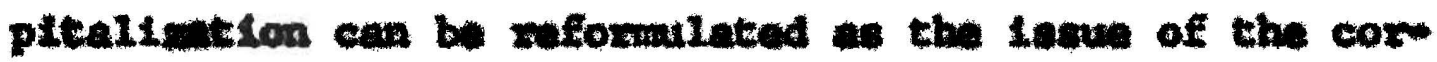
xlation botimen postedischerge devient behavior and readmiserson.

This relutionship hes been tented by a conoldamble muber of authoxe. The studien noguting the eorrelettion

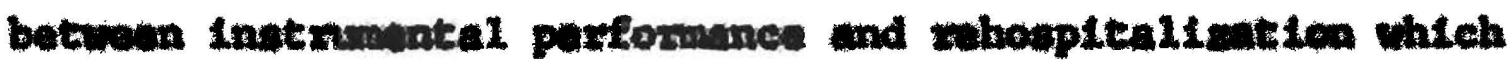
have been etted provicusly cen be seen al dinect teate of the hypothente that soctal doviancy and zubospitalization

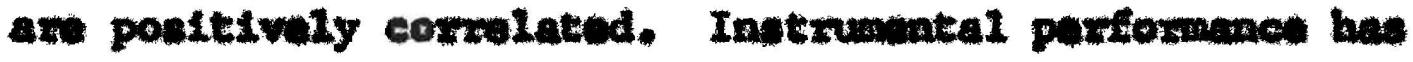
been definad in texwe of behayions which an accoudied hiph velue as appropriate lifencys for adult individuals by a

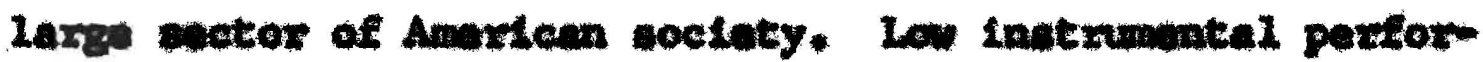
nance, or tallum to engage in these ectivitted, can be weganted sceuratedy as social deviancy.

As wes alweuned provtouly, the mejoxtty of the atudies

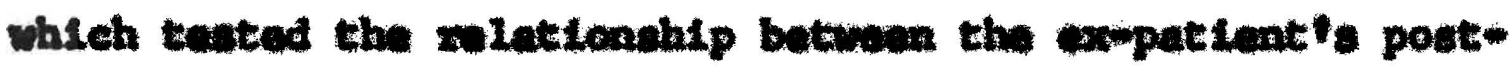
relenes exployment and his ability to avold xubopltalleation cupported the bypothesis that the two vartables are poettivily wieted, although altemativ eplanntion: of these Indinge have not bean zuled out effectivily at this time. These Alndinge alieo offer cupport, then, for the com 
wollaxy bypothaed that soetal davianey, as manteuted by lack of gainful enploymant, to positively welated to whoepitalintion. The fact that alternative tntexpretation of these Elading have not been obviated, bonver, puallfies the auppost which is offexed. The "condidenable overlap" betumen the pout-xilesue woxk recorde of the expatients

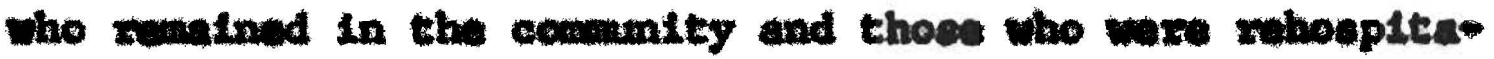
11 wed wich wis ropoxted by Fuemen and 81 mono $(3$, p.50) further andifies ach apport.

Tolven en a wole, the attempte to study the welation ship betwen soctal participation and cownuntty temure thich haw been discusend in the provious chaptex offor scant aupport for the contentica that the tive ax posteivily walated. These findinge also fall to euppoxt, then, the corollaxy hypotheste that soetul eviancy, in the form of social with-

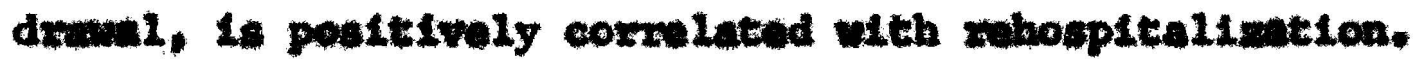
Aleo nelevent to a digeuseton of the relatlonship be-

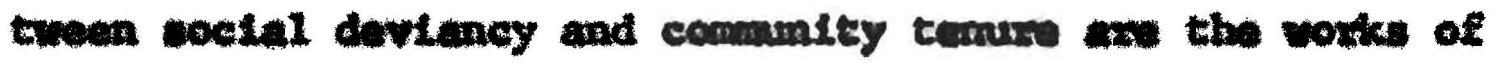
vartous enthore tho have attempted to tent the bypothasto that engaging in behavior which is clesticaliy wharded as "aysptomatic" is positivaly correlated wtth mahopitalizm" tion. Angriet et al. (20) exmined ymptomatic beheviors a point atx monthe after disehaxge in a population

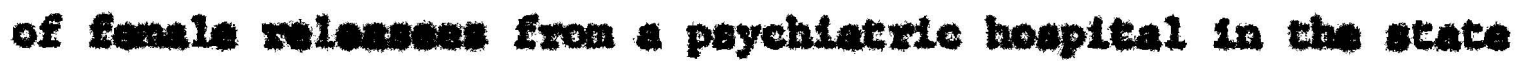
of Ohlo. Symptomatie bohevioxs wre manumed by mane of a structured interview wth a "algatfleant other" of the ex- 
patlent. The wuthors found that $14 \%$ of the expatiente in thalr atudy population had been readnitted to payehiatifie hospitalleation prior to the waluntien. Compurteon bu-

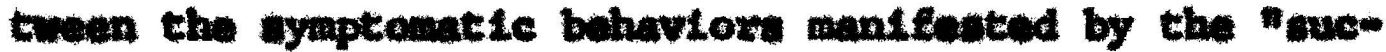

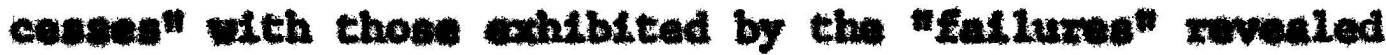
that the copetiente who falled to rwatn in the commentty

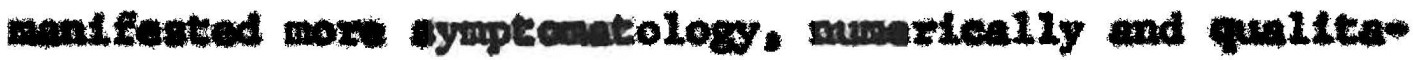
tively, then did the expetinat: who succended in temalnIng in the commenity fuxlug the study perled.

This findlng could be thalleaged, hownex, on the bas1. of the finct that the euthorg" eatimation of the symp" tematic bebeviox of the roturnases we dexived from a roport

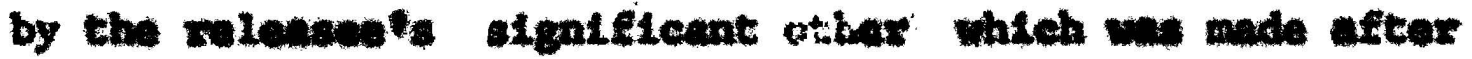
rehospitaliention had oceurxed. A dintinet poselbility exiot. that the weollections of the Agnifleant otherw might have been altened by the ect of suhoupltalination, Itedf. In the direction of Incruaned puchology.

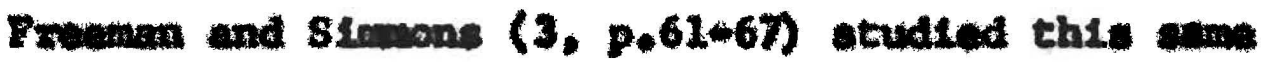

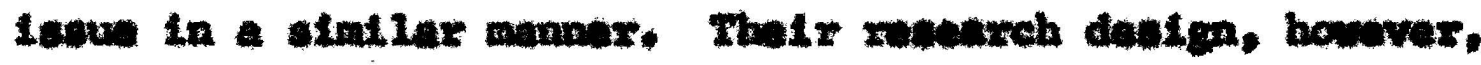

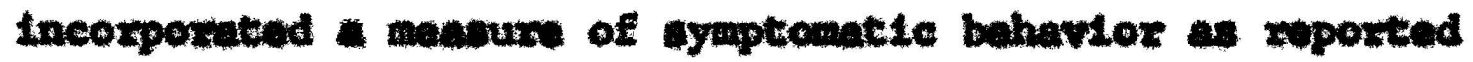

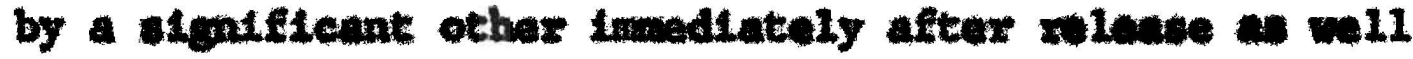

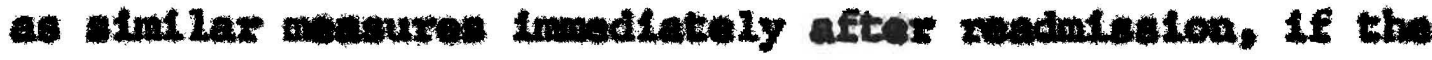
ex-patieat we ruhospltaliead within a one year partod aftax discharge, and at a point one yenz after discharge.

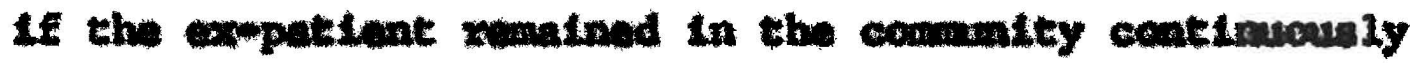
during that tine pertod. These atthors thon conbined the 


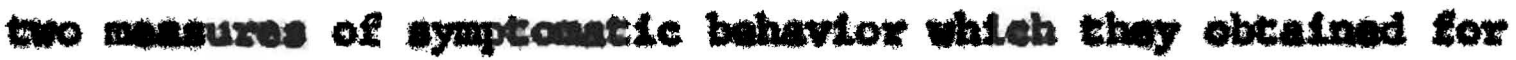
each pationt, in a mannor which thy did not explatn, into a eingle profile of the eyaptomatology of the patlent. These mantures wave then rated along a algele dinanston which the

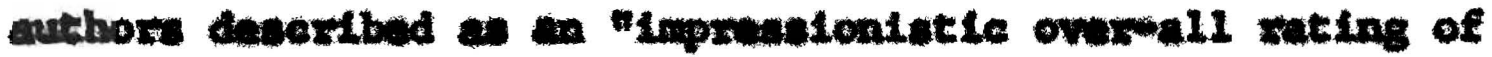

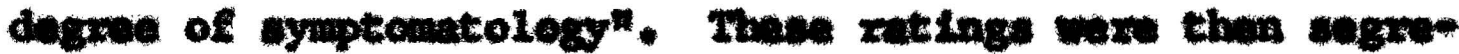

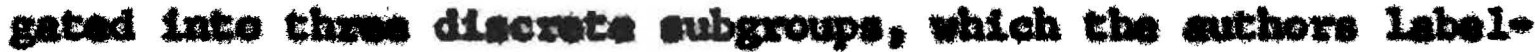
Ied: "Mbormal". "Intermedrate" and Homal". The authors foumd chat dogwe of syptomatologs, as musured by thowe

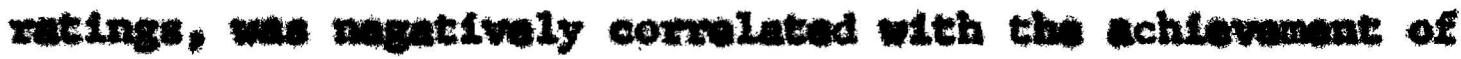
comanity temux.

This atudy, e2so, Imads only gralifted apport to the hypothese that rohoupttaliention is posteivily cormelated wth symptomatic behuviox. The degree of mbjectivity in the author" wathods of encinuting symptomatelogy allow for the posability that factore other than those deseribed by the wuthows could have eccounted for the corralation which thyy found. Alvo, the fact that 45,5\% of the males whom thyy Ibballed as Mbnormal" and 44.4\% of the Abnomal" females in that atudy war able to eatablieb thenelves In the commity "ruceesafully" according to the authors" weenxch exttextion $(3, p, 66)$ lende suppoxt to the hypow

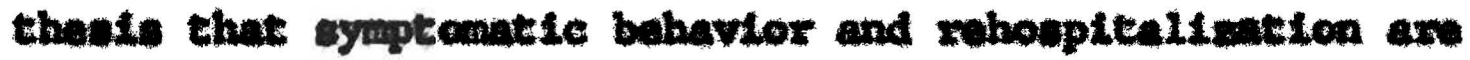
not highly commelated, although this ouppost, too, is quallfled by the degave of aubjectivity which the asthore emm ployed in thet: zatinge of overwall eymptomatology. 
Direot muport for the contention that syuptomatolosy and subopitcalintion awe not highly comelated is eupplied by Mated (13) tho Interviened fandiles of expotiente to obtaln a proflite on each expetiant which walected the extent to which he had mantfeated vartous "mojox"t and "minox"

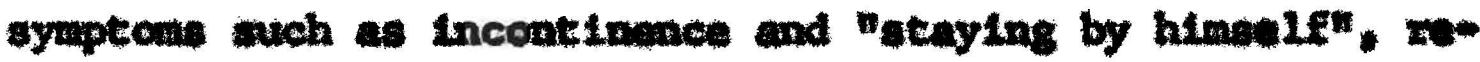
spoetively. The ex-petiente vine then labelled "abnozmal"

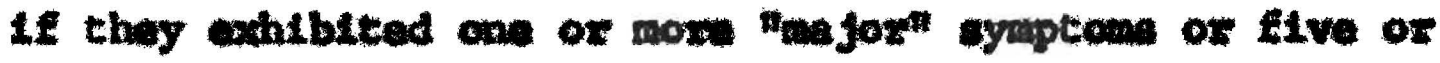
moxe minox" symptom churing the portod following their houpltallation, and "nomal" If thoy dieplaynd no "majox" oymptent and fover than five "minox" one. The withor then compaxed thase antinge vith the exopatiente" ability to wo maln In the commity for on yeax after discharge AIthough he did not compute the correlation botwen the tero variables disectly, be formd that $72 \%$ of the "abnormals"

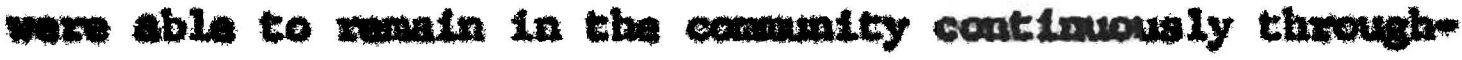
out the exiterion time persod.

Addit Lonal auppoxt for the hypothesic that aymptom

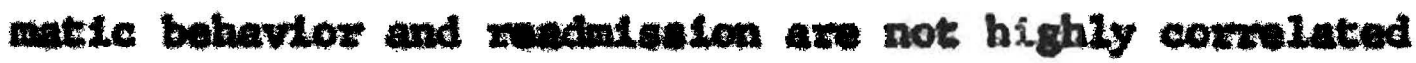

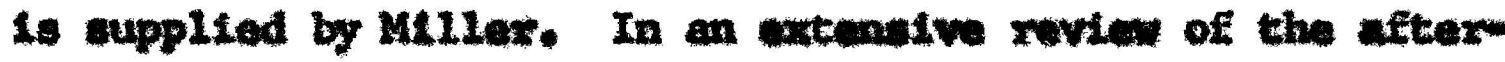

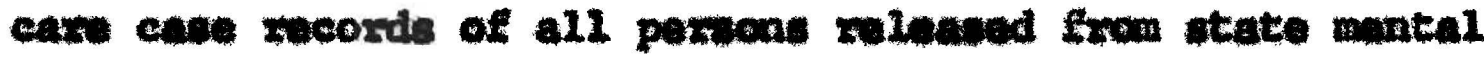

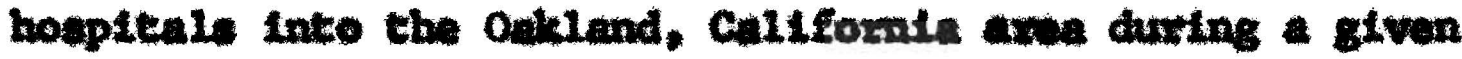
year. wh found that moxe than ons fourth of thowe recoxds "made no mention of any pryehiatrie nyuptonatology ox soelally upsetting behavior present in the patient"s 1Lfe" but that $M_{\text {in }} 4 T$ of such coses the patient was whospltal- 
1zed" $(4, p, 34)$

When viewed as a whole, the strudles which have been cited immediately above suggest that rehospitallzation is not correlated highly with socially deviant behavior as mantfested by low levels of instrunental performance $o x$ by symaptoratic behavior, a? chough significant correlations between gainful employment and avoidance of rehospitaliztion have been found. This finding suggests that the degree of success which the ex-patient experiences in his efforts to establish residence in the commity may be determined, to constderable extent, by factors othex than his behaviox in the conamity. This hypothesis suggegts, In turn, chat achfevement of commity tenure tay be correlated signiflcantis. wth discemible environmental variables.

Consideration of anvironrantal varlables leads initially to on exwinatlon of the environment of the expactent. One primaxy issue which mot be denit with in this segard is the question of the type of restdential settings to which ex-patients are releasad. Researchers who have excmatined this issue repoxt that a slzable majorIty of the persons who are discharged from psychiatric hospitalintion are relensed to farily settings. Wessler and Kahn, in a study of a population of discharged chronte schizophentes in the state of Massachusetts, repoxt that two thinds of this population took up ressdency immediately 


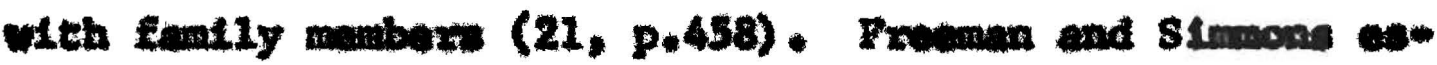
tinate that two thinds of all perzon who axe digecharged

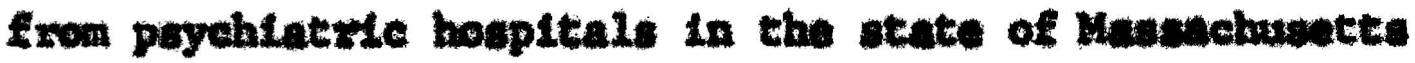

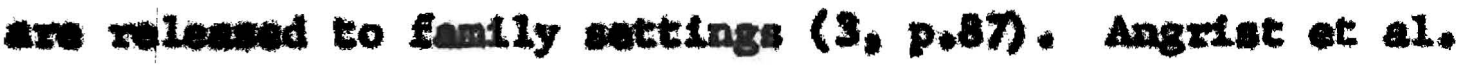
xuponted that 68\% of the fumale expettents whon they studied in the state of Onto xeturned to 11 w wth atthex conjugal ox pexuntel families (9, p.77) silveretein, in a etudy of all pureens of both soxes who wres zolenged fxom

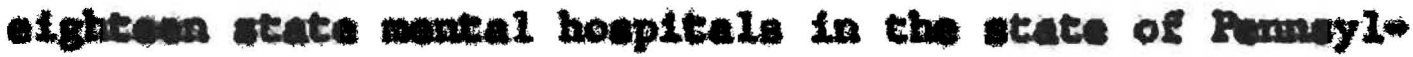
vanil during a particular calendax yeax, found that thwee

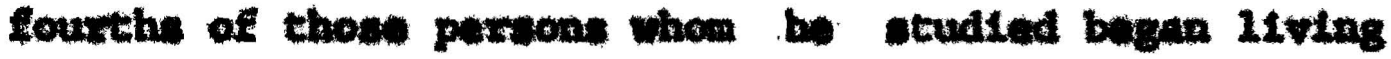

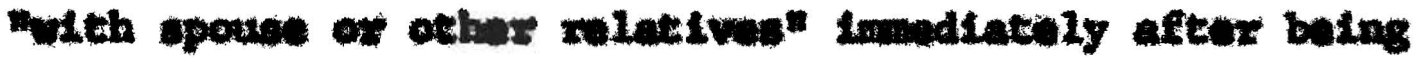
dischanged (1, p.18). Hicharx et al, found that 94.27 of

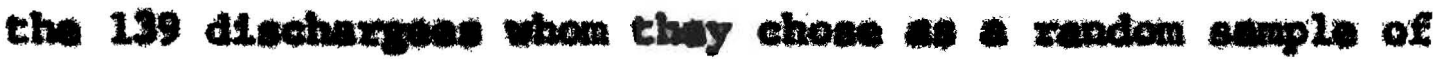

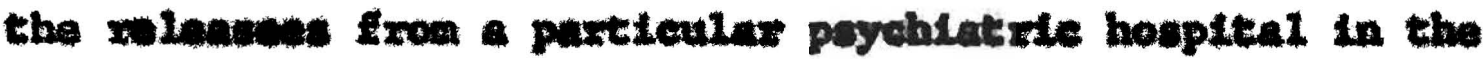

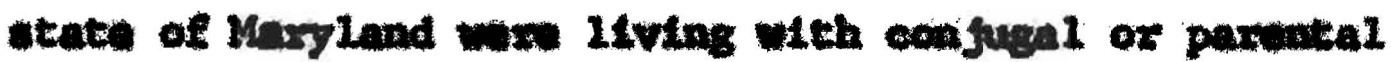
fenilies or with other relatives th thend of the flrst month whteh followed chatr misene (2, p.44). Thene otu-

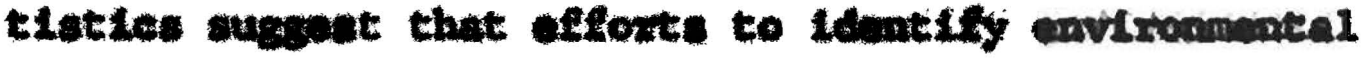
corralates of the chilevenant of cewminity temux by pex-

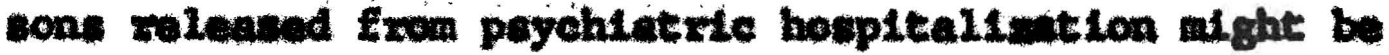
foetued productively on qualittes of the fansiles to whom a majoxty of patiente axe mienaed.

Much bas been wrtten about the wole which the family pleye in maintaining the exppetient"s temuse in the eommonLty and about particular strategtes for profiensional Inter. 
vention in this proceds. Howover, characteristically, thase witers have falled to found thelr asenticens on enplrical evaluations of the issues which they discuss. Son vatter. base conclustons on anecdotal matertal, or amall waple des-

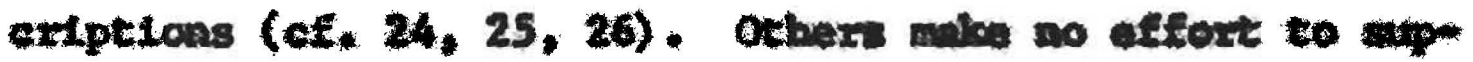
poit thel $x$ contentions wth empizion deta in any form (ef. 27, 28, 29).

Sen authors have attempted to exratne the relation. thip between vertous charecteristies of tho fandilas with whom expatients woste and the ebility of the expontient: to achlove coumunity temure. Thave atudles can be cetegor ited Into four distinct tople axtens: fandly tolentition of the ex-patient/s symptoratte behavlox, kin wole whieh the femily affords to the exmpatient, fenillal expectations of the exwatlents pexformence, and attltudes and perwenality charactexistice of funily nembext. 
CHAPTER IV

TOLERATION OF SMMPTOMATIC BEHAVIOR

Researchers have found that ex-patients who are successful in their efforts to achleve comminty temure may manifest widely varying amounts of socially devlant behavior, in the forms of low instrumental performance and of symptomatology, as has been discussed previously. This fact has led certain authors to hypothesize that the ability of ex-patients to achieve community tenure is correlated directly with the extent to which the families of those patients are able to tolerate the exmpatients" deviant behavior $(30, D .148,31, p .42)$. Efforts have been made to test this hypothesis with respect to the Eemily's toleration of both 10 instrumental performance $(3,4,20)$, and symptomatic behavior $(3,20,21,31,32$, 33). The authors of these studies have used the phrase "toleration of devlance" to describe famillal accomodation in both of these areas. Diatinguishing between the two would seen to have utility, however, in that low instrumental performance and symptomatic behaviox axe discrete phenomena.

If such a distinction is made, grouping studies of tolerance of low instrumental performance with the studies 
of familial expectations of the ex-patient "s performance would also seen to be indicated in that toleration of low performance can be equated with 10 pexformance expectatLons. Those tolerance atudies which ramain could be gxouped under the heading: "tolerance of the ex-patient's aymptonatic behaviox".

Raseatchers have attempted to measure the tolerance which fantiles show towand the syaptconatic behavior of expatients in vaxious wys. Some have attempted to assess such tolerance directly. These efforts have varied considerably in objectivity* Certain authors have attempted to measure famdily tolexance of symptomatology in the expat lent by means of a subjective clinical evaluation of one or more of the fan1ly members $(21,32)$. Othexs have administered a structured quastionaire to a particular fenkly member, asking if a series of symptomatic behaviors would cause hin to contact the hospital rogarding readmission if manifested by the ex-patient in his fanily $(3,20)$.

St111 other authors have attempted to measure symptom tolerance indirectly. Brodsky (33), for example, recorded whether or not fenale ex-patient were employed outside the home and inferred that the environment of those ex-patients who wex not employed outalde the how was moxe tolerant of symptconatic bahavior than the environment of those expatients who were so employed. Davis et al. (31) and Freemand 5 immons $(3, p, 93)$ recorded whathex or not ex-patient: 
retumed to conjugal or parental fomillos and inferred that parental families were moxe tolerant of symptomatic behavior than wexe confugal Eamilles.

These attenpts to measure fantlial tolexance also have been made at different point in the ex-patient 8 post-hospital career. Freenan and stmons attempted to interview the family meraber imediately after the ex-patient"s discharge (3, p,18). Angrist ot a1, (20) and Deykin (32) based their estimations of fanfly tolerance on measurements mede at a point six months after the ex-patient"s discharge. Wesster and Kahn (21) and Brodsky (33) made such measurnents th the end of one year and Davis et al. evaluated the fandiles at a point more than two years after discharge" (31, p.38). The majority of these authors have argued that their findings suppoxt the hypothesis that toleration of the expatient"s symptomatic behavior by members of his family is positively correlated with the ex-patient's ability to achieve corammity cenure $(21, p * 460,31, p+42,32, p+14$, 33. p.179). The data which these authors present in auppoxt of these argunents, however, make use, exclusively, of measurements of femily tolerance which are based upon Inferences of subjective elinical assessments, as discussed above.

Authors who have attempted to evaluate the relationship between dixect measures of fanily tolerence of syuptomatology and the ablilty of the ex-patient to echleve 
conminity temus have reported conflieting results. Angrist et al. found an unexpected negative correlation between the two vartables (20, $\left.p_{*} 366\right)$, while Freenen and Stmons found that the two were not related (3, p.134-35).

It seens that the difference between the conclustons whlch these authors raport might be attributable, at least In paxt, to the differences between the points in the posthospital caneers of the ex-patients at which the authors obtained their neasurements. The fact that Angrist and her colleagues neasured fanily tolerance of symptomatic behavior at a point slx months after the ex-patient's alscharge nocessitated theix evaluating fanily tolerance after rehospitalization had taken place in the ceses of those expatients who wexe returnod to the hospital duxing the atudy period and ware classified as "gatlund" and before rehos" pitalimation among the families of ex-patients who wexe not rehospitalized and were dosignated at "successes". The differmen between these two measures is raflected in the phrasIng of the standardined Interviews which were adminiatexed to the two groups. Relatives of rekurnees were alked whteh syruptons vere actual measons for thei $x$ seeking readrulasion of the patient, whoreas family members of the "successes" wre asked to state, hypothetically, which symptoms would cause then to sook rahospitalination. Measuring femilial tolermee in this mannex does not obviate the possibsilty that apparent differences which are found between the tole- 


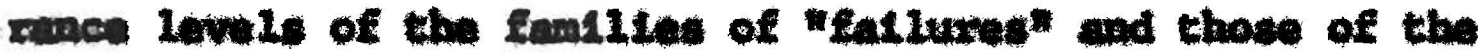

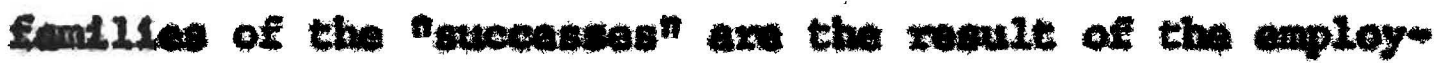
ment of diffexing mansuxenont technigues rather then of actunl differences betaren the tolewrance levels of the two sxoups.

The Elndings of Premen and simons, bouvvex, eamnot be prestioned on this basis. Although the withors state that the practicalitien of wecench aduintetration permitted them only to approcelmate the Ideal destgn of interem vieming a fmily merber immoditaly after the expatients diechaxge and that the waxuge length of time betmeen discharge and the interview was aprostmately 41 doys $(3, p, 18)$. wone of the ex-patients who wax studiad wexe xahospttallad before the fanily interviows took place. The fact that theee authors found no signifleant differmaces in fandly meabere"

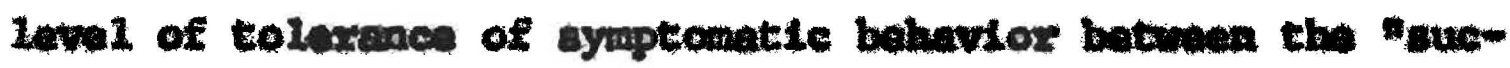
cesp" and "fallume" groups suggeste thet the linear conneletien butween the tolezance of the expetient"s symptenetic behavior by the expettent "s alotive and the expotient's ability to achieve conmmitcy tenwe which would be predicted loglcally may not exdit. 


\section{CuArrar v}

\section{Krm rous}

Cextain authors have also advanced hypotheses xegard Ing the selationship between the kin wole which the expatient's tamliy affords to hin and the axpatient" abilIty to achieve communtty temuse. The win roles which have been coatrated in this ragaxd are those of "chlld" (son or daughter) and "epouen".

Most studies bave found that expotients tho retumn to

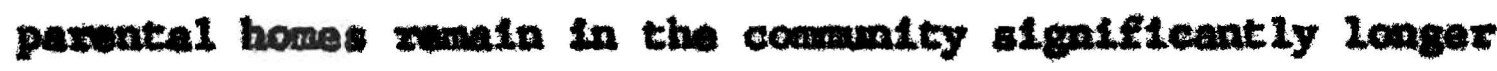
than those who weturn to conjugal famcly settings. Davis ot al. In a study of 126 zelonbees of both soses in the otate of Masudibuects, reported that "euceses" among expattents, as doffned by remaining in the community continwouly for a pertod of two years or longar after discharge. was positively correlated with retuming to a parental as opposed to a conjugal family setting (31, p,40). Caviria and tund studied apulation of 59 consecutive dischargen from a Veterens" Adnintetzation payshiatxtc hospital near Dunver, Coloxado, and found a "sigatficantiy shorter atay In the conandty after diecharge anong patients 1 ving wth the apouse then enong patients 11ving with paxente" (18, D.171). Angriat and ber collevgues exumined a group of 287 
female miensoes from ate psychiatric hospitul in Ohio

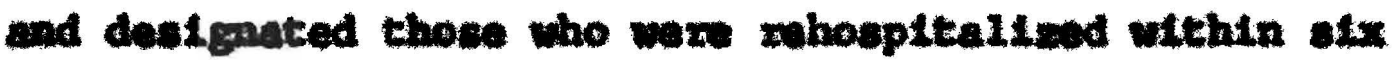
months as "zeturneeg" and those who remalnad in the conmity contimousiy during that time as "expatienti". They reported that "retumaes are more frequantly Iiving in conjugal fandiles than axe ex-patlente" $(20,0.364)$, although this difference wes not statistically stgnificant. Sons authoxs, however, have found the revere rela" tionship. Michavx et al, compared the residential settings of 139 dischargese from a single paychlatmic bospital in the state of Maxyland wth theix conmunity tenume at the end of weh month during the first year after diecharge and found a signiflcant negative correlation between comminity temure and restdunce in parental as oppoesd to conjugal family settings, when mavured at the end of each of the flrst four months $(2, \mathrm{p}, 81)$. Measurements made at the end of each of the subsequent eight months, howover, revealed no sigalflcant corralation $(2, p, 82)$.

Freeman and stranons studied population of 649 relessees I20m state hospitals in Maseachuetts and found that Alechargees of both swras who retunned to conjugal as op-

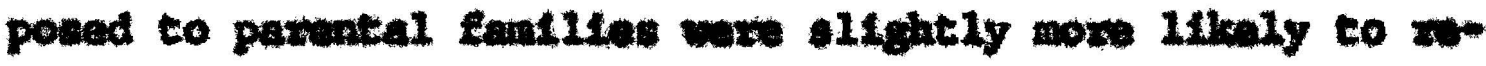
main in the commenity $(3, p, 92)$. This neletionship was not signifleant, hovever.

Constdered as whole, thase findings offer quallfted eupport for the bypothesis that returning to the eoctal- 
biologieal wole of "entld" as oppoed to the kin zole of "opoume" is positivily comelated with achlevenent of coum manty temuse for the expatient. This apparent corrola* tion galne additional atealficance in 11 ght of findings which augenet that maxified ex-patients paxform at higher Ievels and manifent fewex aymptematic behavioxs than do etngle exmpetiente (cf. $33, \mathrm{p}, 170,34, \mathrm{p}, 624-30$ ). It nems that ex-patiant "chlldren" may remain in the cownuatty longar than ex-patlent hubands and wives despite the fect that thoy axe "sicker".

Initially, authors attributed the apparent longer stays in the comonity of persons assuming the vchild nole to the fact that parents were mome tolerant of deviant behavior than were spouses $(30, p, 148,31, p, 42)$. As has been discussed above, attempts to assess the relationship between the fandiy"s toleration of the ex-patient "syuptomato108y and the ex-patient's ablitty to achieve conminity tewure have not aupported the hypotheals that the fenily's tolexance of that form of doviance is solated to the expatient's commentty tenurre.

As we also direused bove, some of the deviant be* haviox which characterlwes mental 111 wess talees the form of 100 indtrumental pexformence rather than oymptonatology. Along thace 11nes, It could be argund that the kin xole of ehild Is mow conductve to the exmpatient's com-

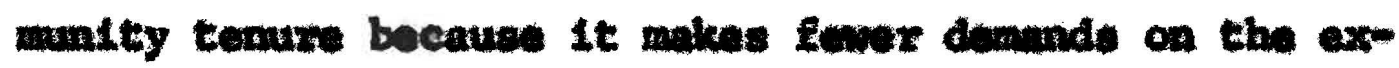


patient wth zagard to inatrumental poxformonce and, bence.

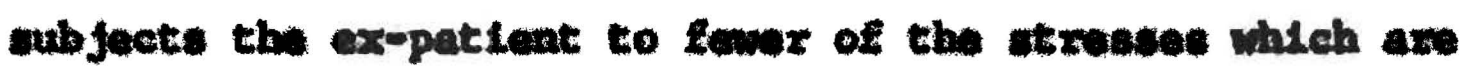
asscelated wth sweh demands. 


\section{ciarat v

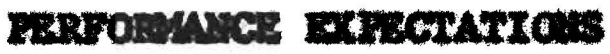

DAwet attempts buve been made to tent the hypotheols that the abiltty of the expatient to avold mboupita. Itatien is negatively corrulated wth the dagree to whteh

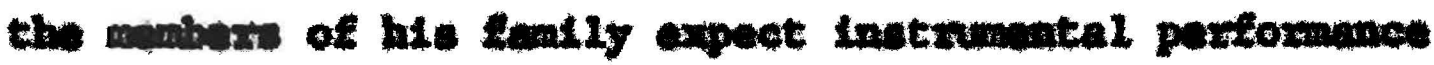
of hin. Angrtet et al, (20) selected out the 287 ex-pa"

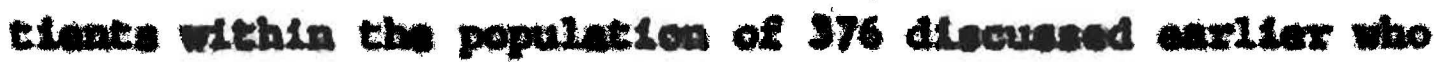
raturned to fandiles within th imodinte velnity of thetr

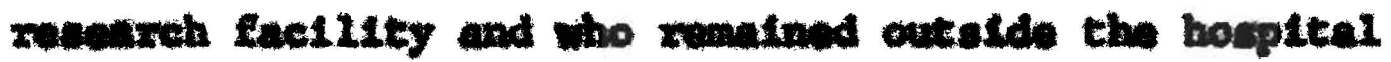

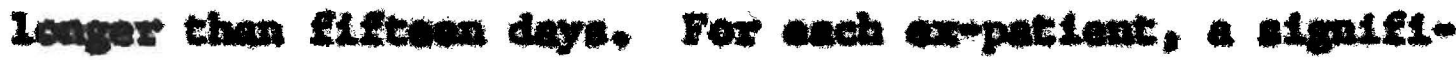

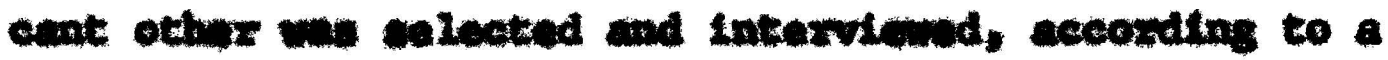
etandard proendure. The intervieve took place ct a point

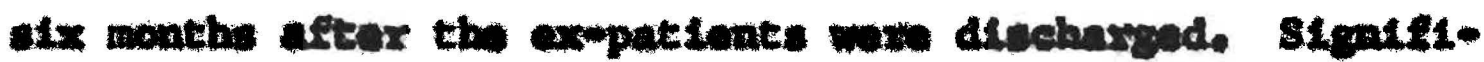

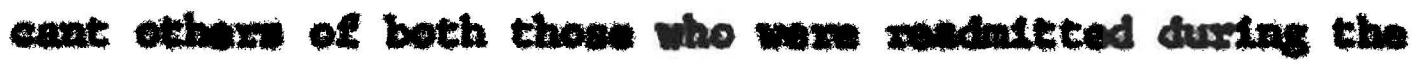

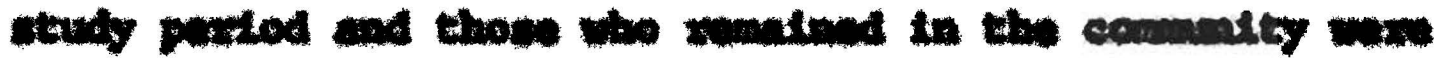
soked which of axtes of ingtranental behaviox thoy ex-

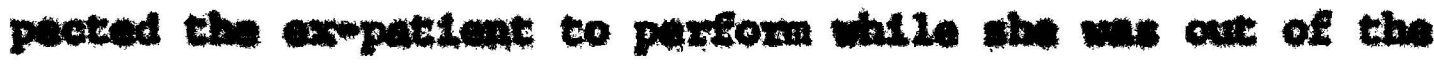

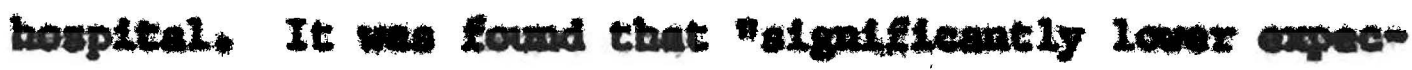
tetlens wax bid fox the renditted group" (20, p.365).

This Ilnding offorrs support for the concention that

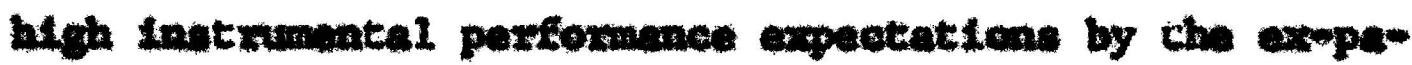
tiant is fantly at a potnt six month after digehaze and 
echtevement of coumuntty temuxe by the ex-patient axe posttivaly corrolated. The date do not auport the fuxthar assumption that high performance expectations an conduetve to remaining in the comminity, however. The postelve correlation between high expectations and ouceantul ad juntment to committy living may ofmply zeflect a proceas of

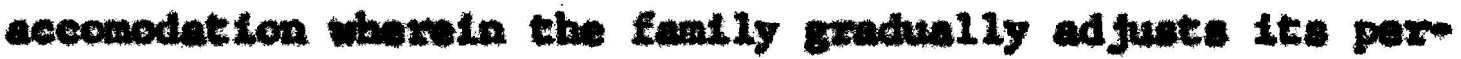
formanee expectations tovaxd conformity with the cetual performance of the exppatient in the comminity. The authore acknowledge this posstbility $(20$, P.369) and speculate leewhere (22) at som length as to tha wewhales of weh an ceecendution precess $(9, p, 170-72)$.

Miler (4. p.54-62) appeare to hawe lgnored the poo" stbillty thet weh changen in the fanily' performance expectations owex tim alght oceur. She roviened the cusem

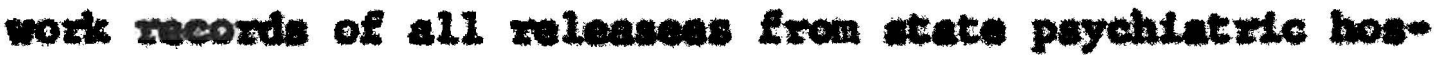
pitale who took up renldence in the Oaklend, Calffornta axa tmodiately after dischaxge, and made atngle overall rating of the level of the Instruanatal performance expectation which the ex-patient's fendly, as a unit, had

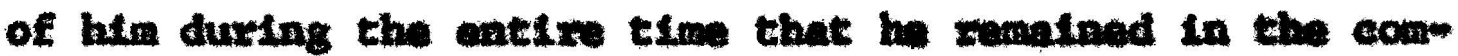
munity. She then divided the uxpatients scconding to the kin role which thy aseuned upon relases and computed the correlations between the expectetion rutings of the temL110 and the commanity teaure of the Individuals in ench group. She found no stgaffeant coxnelntion botween the 
two varlables in the cases where the ex-patient retuxned to the kin roles of "husband", "wife", "son", or "daughter" (4, p.55). A significant positive correlation between the rating of fandilal performance expectations and community temure was found, however, in the case of those Individuals who returned to the kin role of "other relative" $(4, p, 55)$. Freeman and SImmons (3, p.139-55) have recognized the fact that changes in fanily expectations might occur over time as a result of interaction with the ex-patient and have attempted to control for such changes in a research design by measuring familial expectations of the ex-patient at the time of discharge. These authors located a significant other for each of 649 state mental hospital releasees. In a structured interview, they presented a list of instrumental performance behaviors to the significant other and asked which of those behaviors the significant other would expect of the patient at a point three months ahead of the time of the intervieu. The significant other was then asked which of the behaviors would be expected at the end of one year. The list was then presented to the significant others two more times. Prior to the first of these, the significant other was asked which of the behaviors he actually belleved the ex-patient would be performing at the end of a year. Before the last presentation, the significant other was asked to designate those behaviors which he would insist that the patient perform at the end of one year. 
The authors then added the number of positive responses in each sertes to obtain scaled scores reflecting: the level of the significant other's predicted expectations of the ex-patient's behavior at the end of the three month and the one year periods; the level of actual performance at the end of one year which the significant other predicted; and the level of pexformance which would be insisted on at the end of one year, as predicted by the significant other. Intercorrelations between the scale scores as well as correlations between each of the scale scores and the ex-patlents' ability to achieve community tenure were then computed.

The authors found that the scale scores were highly intercorrelated, indicating that the significant others did not foresee their expectations changing greatly over time and that they felt that the ex-patients" level of actual performance would probably colncide with the levels which they would expect and insist upon. None of these measures, however, were correlated aignificantly with the ex-patients' ability to achieve conmunity tenure. This latter finding militates strongly against the usefulness of hypotheses relating famillal expectations to rehospltallzation. As has been discussed above, correlation between expectations measured at points after discharge and rehospitalization has Ifttle explanatory value because of the likely interplay between the two variables. Correlation between expectations measured at the time of discharge and ability 
to achleve community tenure would have utllity in this regard, but the reaults of Freeman and Simmons' study indicate that such correlation may not exist. 
CHAPTER VII

\section{FAMILY ATTITUDES AND FERSONALITY CHARACTERISTICS}

Authors of the last group of studles in this area have turned their attention toward measurable family attitude variables other than toleration of symptomatology and expectations as well as toward personality characteristics of fanily members, in an effort to identify correlates of the ex-patient's ability to remain in the community. Freeman and Simmons $(3, p, 105-120)$ attempted to measure fanily personality charecteristics by administering the "Anomia", "Authoritarianism", "Frustration", "Rigidity", and "Withdrawal" scales developed by Srole and his associates (35) to a significant other of each of the 649 state mental hospital releasees in their study cohort during an interview which took place immediately after the ex-patient's discharge. This interview also included the administration of the "Aut1sm", "Cyclold thinking", "Emotionality", "Nervousness", "Dominance", "Persistence", "Self-confidence", "Self-sufficlency" and "Impulsive-rathymia" scales developed by Brim et a1. (36) and the Borgatta-Corsini rQuick Word Test" (37). In addition to the structured persons1ity sceles, the interviewers recorded global ratings of the Informants, according to scales developed by Borgatta (38), 
on the following personality characteristics: "Activity", "Solldarity", "Intelligence", "Tenseness", "Initiative", "Understanding", "Rationality", "Upsetab1l1ty", "Suggest1veness", "Likabllity", "Clearmindedness", "Nervousness", "Assertiveness", and "Emotionality". These ratings were then factor-analyzed and it was found that they clustered Into an "intellectuality" factor (Rationality, Cleamindedness, and Intell4gence), an "excltability" factor (Nervousness, Tenseness, Upsetability, and Enotionality), an "Independence" factior (Initlative, Assertiveness, Activity, and Suggestiveness), and a "soclability" factor (Understanding, Solidarity and Liability). Correlations between each of these fanily personality tralt measures and the ability of the ex-patient to remain in the community contimously for one year were then computed.

It was found that none of the Srole scale measures were signiflcantly correlated with the ability of the expatients in the study group to achieve conmunity tenure. Similarly, none of the Brimm scales distinguished between the families of the "successful" and the "unsuccessful" releasees. The authors also found that their a(Yuick Word Test" ratings of the intelligence of the significant others were not correlated with the ex-patients' ability to avoid rehospitalization and that the interviewers over-all ratings of the family members' personality characteristics, when considered both individually and in the form of the factors described above, were unrelated to the communty 
tenure of the ex-patients.

Although the valldity of the varlous techniques of measurement which Freeman and Simmons employed could be challenged and hypotheses could be advanced relating community tanure to family personality varlables other than those which the authors attempted to measure, the fact that their efforts did not result in the identification of even one family personality characteristic which correlated with ex-patient commuity tenure suggests that such correlations may be difficult to measure if, indeed, they exist.

Studies attempting to relate familial attitudes other than tolerance of symptomatology and expectations to expatient cormunity tenure include the works of authors who have endeavored to make a single, global, assessment of the amotional orientation with regard to the ex-patient of one or more of the ex-patient's family members. This over-all orientation has been labelled variously as "intereat" (21, p.458), "benevolence" (17, p.84), "positive attitude" (18, p.166, 4, p.55), and "over-all acceptance" (39, p. 390).

The methodologies which these authors have employed In their efforts to measure this orlentation have been similar and consistentiy lacking in objectivity. Wessler and Kahn (21) asked trained interviewers to make a subjective clinical assessment of the degree to which the 


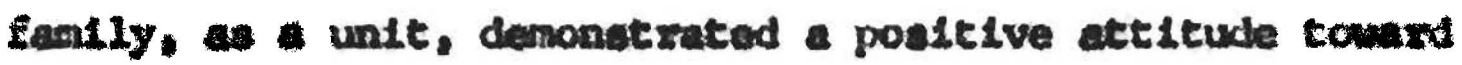
the exppatient. Axthur at al. (17) asked their trained

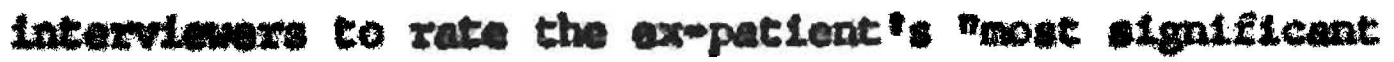
relative" on a Iinour seale as to his benevolence towand the ex-patient. Caviria and Lund (18) anked psychiacric coctal wosture to review the case records of the ex-petiente In their study cohort and to assess, retroactively, tho posItiveness of the attitcudes which thatr fartilea sboned towand then at the time of adaiesten, and Kolly (39) alked trained soclal woxtcons, who were fendliar with the expatient to fanly exvironuent, to rate thowe relatives with whon they had had auffictent contact os to thair acceptance of the exppatiant, on a fourmpolnt scale.

The ut1lity of efforts of cartain of these wuthors is compromised further by tha fact that they attermpted to mee* oure family attitudes at points subsequent to the ex-patlent 's discharge. It whe argued above that comelations batween fandly expeotations meavured at polats aftar the

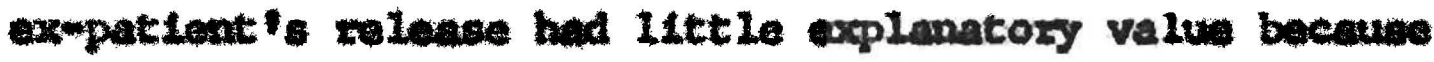
of the Likely interplay between fantily expectitions and the exmpatient 's experiences in the conmunity. A atmilar axgument could be advanced with regard to fandly attltudas in generel. If a positive comelation betwen the farnily's over-all attitude towind the ex-patient and the expow tient': ability to remaln in the comunity were found, such a finding would support efther the hypothosis that 
a positive attitude toward the ex-patient on the part of the family 18 conducive to the ex-patient's remaining in the conminity, or the alternative hypothesis that expatients who achleve commity tenure engender positive affective responses fron thair families. The studies of Wessler and Kahn (21), who endeavored to measure fanlly attitudes at a point one year after the ex-patient's discharge, and Arthur et al. (17), who attempted such measurements three months after the release of the ex-patient, are subject to this criticism.

The two remalning studies report conflicting results. Gavirla and land (18) found a significant positivo coprelation between their retroactive estinate of the positiveness of the attitude of the famliy towand the expatient at the time of his most recent admission and the ex-patient's ability to achleve tenure in the community subsequent to his discharge. Kelly (39), however, found no correlation between the assessment of fanily acceptance which he made during the patient's hospitalization and the patient's ablilty to avoid rehospitalization. The fact that Kelly rated family attitudes which existed at the time of the rating and that he made such assessments on the basis of personal Interviews rather than case records would seem to give his findings greater weight than those of Gaviria and lund. In any case, definitive support for the hypothesis that the over-all enotional 
orientation of the family with regard to the ex-patient is correlated with the ex-patient's ability to achleve comanity temure is not provided.

In a more focused study of family attitudes, Linn ( 7 ) attempted to test the hypothesis that the extent to which family members regard the ex-patient as being "sick" is essociated with the ex-patlent's ablilty to avold rehospita-

1ization. In this study, the author sent questionaiines to familles of all male psychtatric patients who were readmitted to a particular Veterans Administration Hospital during a given three month perlod. The questionnaires asked the relatives to rate the degree of pathology which was man fested by the patient during his last sojourn in the comminity, Linn then divided the patients into the categories of "short" and "long", according to whether or not the ex-patient had remained in the comminity less than or more than one year, respectively. Correlations were then computed between the length of time the patient zamained in the community as rated and the extent to which the family viewed the ex-patient's communty behavior as pathological. A significant negative correlation between the two variables was found. The explanatory value of this finding, too, however, Is lessened considerably by the fact that retroactive messurement of fanily attitudes was employed.

In a final related study, Freemen and Simmons (3, p.16270) attempted to measure the atrength of the feelings of 
st1gma which were experienced by fanilies of ex-patients in addition to certain general attitudes toward mental 11 iness which family members held. The authors attempted to measure family feelings of stigna at a point immediately after the ex-patient's discharge by means of a flve iten scale which asked the relatives of the 649 mantal hospital releasees whom they studied direct questions regarding how they felt the conmunity viewed the return of the ex-patient. Responses to the five items were then coded numerically and totalled to yleld numerical ratings of the families' feelIngs of stigma. Correlations between these ratinga and the abilities of the ex-patients to avold rehospltalieation were then computed. No significant correlation was found. Attitudes toward mental illness in general were assessed by means of four attitude scales of four items each. These scales, too, were adninistered to family members immediately after the ex-patient's discharge. The flrst of these scales was designed to measure the extent to which the family members belleved that patients can recover completely from mental 11lness. The second scale represented an atterpt to assess the degree to which the family menber saw mental patients as being responsible for thoir condition. The items which made up the thixd scale were designed to evaluate the relatives' attitude toward mental hospitals and the fourth seale contained itens which represented attempts to measure the extent to which the family 
viewed mental 11 iness as being psychologically, as opposed to biologically, detemined. Scale scores were again obtained by totaling coded iten responses and correlations between each of the four series of scale scores and expatient rehospltalization were then computed.

It was found that the first two serles of scale scores were positively correlated with ex-patient commity tenure. The authors found a "weak trend" in the direction of correlation between the thixd series and community tenure, and no correlation between comminity tenure and the fourth series of scale scores. The significant relationghip involving the first serles of scores which was reported was a positive correlation between relatives' bellef that mental patients can recover conpletely and ex-patients estabIlshing community tenure. The significant relationship involving the second sertes of scale scores was a positive corralation between the view that mental patients are not to blame for their 11 lness and communty tenure. The "weak trend" which the authors speak of with reference to the third series of scores is in the direction of positive correlation between ex-patient commity tenure and a positive attitude towand mentel hospitals on the part of the family. The fact that these findings are based on attitude measurements which were made at the time of discharge gives then greater explanatory value than the findings of authors who employed retroactive measurements in that a predictive 
relationship has been eatablished. It might be predicted, on the basts of these findinge, that patients who are released to fanilles who belleve that peopla cen recover fully from mental disorders and that mental patients are not responsible for their affliction will be more likely to avold rehoopitalization than those who return to fandIles holding opposing views. Further asgumption that such views actively facilitate commity tenure is speculative, hovever, in that the study which is discussed above does not disprove the hypothesis that such attitudes the result of previous experiences with the ex-patient which are correlated with his ability to avold rehospitalleation rather than actual determinants of this ability. Vlewing efforts to Identify family attitude and personality characteristic correlates of ex-patient conmunity temure, as a wole, it mut be concluded that such efforts have met with little success. Certain correlations between retroective measurements of the family attitudes and the ex-patient's ability to avold rehospitaIIzation have been found but these have little explanatory value. The findings of Freenan and Simmons which are discuswed above, however, offer hope that more meeningful family attitude correlates may exist. 
CHAPTER VIII

CONCLUSIONS AND IMPLICATIONS

$$
\text { I. SUMMARY }
$$

The pattern of frequent discharges and readmissions which characterizes most psychlatric hospltalization in this country today has been described briefly. It has been argued that the costs of this "revolving door", both to the individual patients and to soclety, outwelgh such benefits as might be derived from it. It also has been acknowledged, however, that positing the inacceptablilty of this pattern of service delivery necessitates addressing the 1ssue of alternative treatment goals and strategles. Community tenure and ingtrumental performance have been compared as aftercare goals and interrelationships between the two have been explored. A stepwise progresston aftercare model, simflar to that which was introduced and later re jected by Freeman and Simmons (3), has been proposed. ThIs model has identified community tenure as the most appropriate goal for inftial intervention efforts. Maximization of the ex-patient's instrumental performance has been viewed, in terms of this model, as a second-stage goal which should be addreased only after the ex-petient's conmunity temure has been es- 
tablished, and only if such performance is consistent with the ex-patient's continued residence in the community.

Attempts to identify correlates of the establiohment of community temure by mental hospital releasees have been reviewed. It has been found that the ex-patient's ability to achleve comminfty tenure is not highly correlated with the extent to which he manifests deviant beinavior. This finding has been interpreted as an indication that environmental factors may play a significant part in the expatient's ability to avold rehospitalization.

In an effort to begin to examine the environment of the ex-patient, data regarding the settings to which persons are released after psychiatric hospitalization in this country have been presented. These data have indicated that a clear majority of these releasees take up residency inmediately with family members. It has been hypothesized, then, that measurable family variables are correlated with the ability of the ex-patient to achieve conminity tenure.

An attempt has been made to examine this hypothesis In the ilght of relevant research. It has been achnowledged that many authors have discussed the role which the family plays in maintaining the ex-patient's tenure in the communtty. Many of these otudies have been excluded from consideration, however, because the assertions which they contain are not supported adequately with empirical data. Studies of this 1ssue which do contain substantive empiri- 
cal support have been categorized into four toplc areas: family toleration of the ex-patient's symptomatic behavior, kin role which the family affords to the ex-patient, familial expectations of the ex-patient's performance, and family attitudes and personality characteristics.

Toleration of Symptomatic Behavior. The authors of this group of studles have attempted to assess the degree of correlation between the capacity of the exp-patient's fan11y to tolerate symptonatic behavior on the part of the ex-patient and the ex-patlent's ability to avoid rehospitalization. Research efforts which involved measurement of this capacity by various means and at different points in the ex-patient's post-hospital career were reviewed. Certain authors reported findings which indicated that a positive correlation exists. It was noted, however, that each of these authors employed methods of measuring family tolerance which were heavily dependent upon either inference or subjective clinical assessments, Two of the studies which were discussed reported efforts to measure famlly tolerance more directly and objectively. The authors of the firat of these found a negative correlation between family tolerance of symptomatology and ex-patient comminty tenure. It was noted, however, that these authors attempted to measure family tolerance at aifferent points in the post-hospital careers of the Individuals in the two ex-patient groups which were 
compared and that their findings could have resulted solely from this difference. Findings of the second study could not be questioned on this basis. Authors of this study measured family tolerance at the same point in the post hospital career of each ex-patient and found that it was not correlated significantly with the ex-patient's ability to reasin in the commmity. It was argued that this findIng Indicates that the Iinear correlation between the two vartables whtch would be predicted logically may not exist.

Iin Roles Authors of studies in thi category endeavored to explore the relationship between the kin role which the ex-patient's family affords to hin and the ex-patient's ability to echieve commity tenure. Speciflc kin roles which were contrasted in this regard were those of "child" (son or daughter) and "apouse". Findings of a majority of these studies, in which subjects were matched as to age and number of previous hospitallzations, offer support for the hypothesis that retuming to the social-blological role of "child" as opposed to that of "spouse" is positively correlated with achleving comminity tenure for ex-patients although conflicting rasults were also reported. It was noted that these findings gain additional algnificance in 1ight of additional findings which suggest that married ex-patients perform at highex levels and manifest fewer aymptomatic behaviors then do single ex-patients. It was hypothestred that the kin zole of child was moxe conduclve 
to the ex-patient's achlevement of community tenure because 1t made fewer demands on the ex-patient with regand to Instrumental performance and, therefore, sub jected the expatient to fewer of the stresses which are assoclated with such demands.

Fanily Pexformance Expectetions, Studies in this category afforded the opportunity to test the interpretation of the kin role findings which hypothesized that low famlly expectations of instrumental performance on the part of the expatient were conducive to the ex-patient's avoldance of rehospitalization. Findings were reported which indicated that there is a significant positive correlation between ex-patient commity temure and fanily expectations as measured at points after the ex-patient's discharge. It was argued, however, that such correlation had little explanatory value becauge of the likely interplay between the two variables.

Another study was reviewed, however, whlch took the possibility of such intexplay into account by measuxing familial expectations at the time of discharge. The authors of this study found no correlation between familtal pexformance expectations measured at this point and the releasee's ability to renain in the community. It was axgued that this finding allitates strongly against the usefulness of hypotheses relating famillal expectations to rehospitalization. 
Fanily Attitude and Personality Characteristics. Authors of the otudies which were included in this last category examined measurable family attitude variables other than toleration of symptonatology and expectations as well as personality characteristics of family members in an effort to Identify correlates of the ex-patient's ability to remain in the community. Findings were reviewed which indiceted that netther the intelligence of fanily member nor charactertstics of their personality, as measured on standardized scales or by clinical judgment, are related to the ex-patient's ability to remain in the community.

Attempts by certain authors to make a single, global, assesment of the enotional orientation toward the expatient of one or more of the ex-patient's family members and to correlate this measurement with ex-patient rehospitalization were also discussed. It was argued that these studies vere of questlonable utility because of the degree of subjectivity which was involved in the attifude measurements which they reported and because of the fact that such attitude measures were made retroactively.

An attempt to measure the mount of correlation between the ex-patient's ability to avold rehospitalization and the extent to which his family views his comminity behavior as being pathological was also discussed. A positive correlation between the two variables was found, but It was argued that this finding, too, had only maxginal 
ut111ty because of the fact that the authors of the study measured family attitudes retroactively.

A final study was revlewed, wherein famillal feelings of stigmatization and family attitudes toward mental 111ness in general were rated at the time of discharge and correlations between these ratings and the ex-patient's ability to achieve community tenure were computed, No correlation was found with regard to the families' feelIngs of st Igmatization. The authors did find, however, that ex-patient community tenuxe was positively correlated with relatives' bellefs that persons can recover fully from mental disorders and that mental patients are not responsible for their affliction. The latter findIngs were discussed as having prēdictive value but as not offering direct support for the further assumption that such beliefs actively facilitate the achievement of community tenure.

Although it was concluded that efforts to discover meaningful family attitude or personality characteristic correlates of ex-patient community tenure have met with Ifttle success, it was noted that the positive correlations between such tenure and family attitudes toward mantal Illness which have been discovered offer hope that other meeningful family attitude correlates may exist. 


\section{CONCLUSIONS}

After examining the hypothesis that measurable family vartables are correlated with the ability of the ex-patient to achleve conunity tenure in light of the relevant empirical research which has been presented, it aust be concluded that very ilttle support for this hypothesis has been provided. Authors of the majority of the atudies which have been reviewed have reported that no significant correlation existed between the family variables which they attempted to measure and the ability of the ex-patients whom they studied to avoid rehospitalization. Most of the positive correlations which have been found have ilttle explanatory value in that they were based on retroactive measurement of family vartables and, therefore, did not take Into account the poselbility of interplay between those variables and the ex-patient's behavior in the community. Among family variables measured at the time of discharge only two correlates have been Identifled. A major1ty of the authors who examined the relationship between the kin role which the ex-patient's family affords to him and the ex-patient's ability to achleve community tenure have found a positive correlation between returaing to the "child" as opposed to the "spouse" role and remaining In the commity, although other authors reported conflicting results. Similariy, a positive correlation between 
ex-patients' ability to avoid rehospltalization and relatives' bellefs that persons can recover fully from mental 111ness and that mental patients are not to blame for their affilction has been discovered.

\section{IMPLICATIONS FOR PRACTICE}

It would be boped that an examination of emplrical research regarding the relationship between qualities of the fanilles to whom persons discharged from psychiatric hospitalization are relensed and the ability of those persons to avold rehospitalization would provide the besis for speciflc recommendations which would assist fanilles of expatients and mental health professionals who work with such families in efforts to maximize the ex-patients ability to remain in the community. Unfortunately, this hope cannot be reallad at this time. The review of research in this arean which has been undertaken here has led to the conclusion that little is really known about the relationship between family varlables and ex-patient community tenure.

It can also be ween that those correlations between the two variables which have been found have provided little information which is directly applicable in aftercaxe efforts. The studies which have been clted lent qualified support to the hypothesis that the role of "child" is more conducive to the achlevement of community tenure for the ex-patient then is the role of spouse. This would suggest 
that ex-patlents should be returned initially to parental rather than conjugal familles in order to maximize the probability that they will avold rehospitalization. It 邦ens unlikely, howevex, that this option would be available in the majority of cases.

This kin role hypothesis could also be applied in aftercare planning efforts. On the basis of these findings, it could be predicted that those ex-patients who return to the role of opouse as opposed that of "child" would be more likely to be rehospitalized and, hence, would have greater need of Initial aftercare services if community tenure were the Initial goal of aftercare.

Mental health professtonals who attempt to apply the kin role hypothesis in either of these two ways should remain cognizant, however, of the fact that the hypothesis has only qualified empirical support. Authors whose studies are cited above have found elther no correlation or the opposite lationship in certain populations. Similarly, the findings which suggest that ex-patients' achievement of comminity tenure is assoclated with the ex-patients families holding the bellefs that persons can recover fully from mental disorders and that mental patients are not responsible for their afflictions could be applied in plaming efforts. These findings could be used to predict that ex-patients who return to relatives holding alternative views would be less 1ikely 
to remain in the community and, therefore, would be in more need of aftercare services if remaining in the commity were the initlal aftercare goal.

These rather limited suggestions seem to encompass the practice applications which can be drawn from the research which has been reviewed.

\section{IMPLICATIONS FOR RESEARCH}

It has been concluded that the research which has been reviewed has provided very little support for the hypothesis that measurable family variables are correlated with the ability of the ex-patient to achieve conmunity tenure. It would seen that two alternative interpretations of this finding could be made. If the studies which have been examined were regarded as valld tests of the hypothesis that family variables and ex-patient community tenure are correlated, then it could be argued that the findings indicate that the two variables are not related and, pexhaps, that fanily-based interpretations of the phenomenon of rehospitallzation are not likely to be productive. If, on the other hand, these studies are viewed as invalid or insufficient tests of the primary hypothesis, then it could be argued that further testing is necessary.

It would seem that adopting the latter position is indicated in that the research efforts which have been reviewed have not constituted an exhaustive study of the topic. 
As has been discussed earlier, many of the authors of these studies have chosen to measure fanily variables at points after the ex-patient's discharge and, therefore, have seriously conpromised the utility of their findings. Those authors who have attempted to measure fanily variables at earlier points have often done so by recording a neasurement based on examination of a single significant other of the ex-patient and equated that measurenent with a neasurenent of the ex-patient's Family. Clearly such generalizations involve considerable risiks.

It would also seem that the studies which have been reviewed could be criticized at a nore basic level in that even those which were referred to as "direct" did not enploy methodology which incorporated attempts to actually observe and evaluate the phenonena which were neasured. Typlcally, these studies obtained fanily variable data by means which were dependent upon "self-reports" by family nembers.

These inadequacies in existing research on the topic would indicate that the hypothesis that measurable family variables are correlated with ex-patient comunity tenure has not been evaluated adequately and that further studies of the issue should be undertaken. However, the consistent failure of those attempts to discover fanily correlates which have been made suggests that such correlates may be difficult to identify if, indeed, they exist. 


\section{Daradness crato}

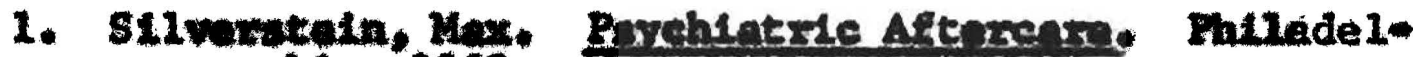
phita, 1968.

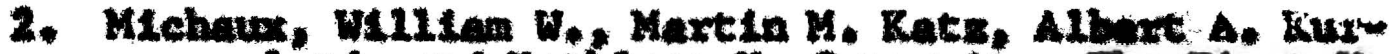

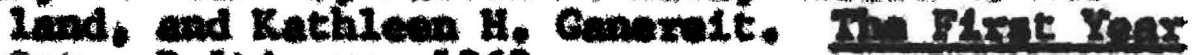
Out. Bultimont. 1969.

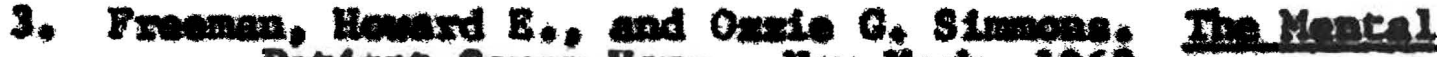

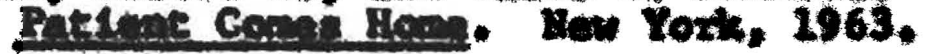

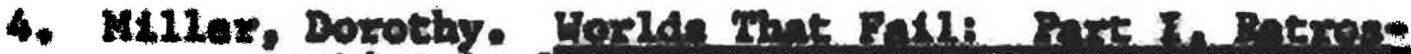

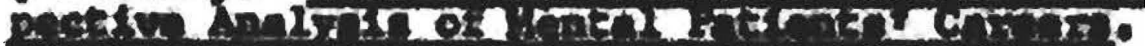

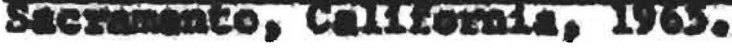

5. Gazanx, H. H. Hoopttalletion - A Destrable Prose-

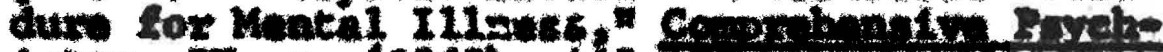
Lex, Ix, v, (1968), 465m/4.

6. Bromn, Ceores V. NChanging Patters of Carre of the

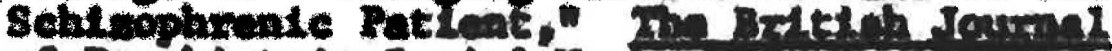

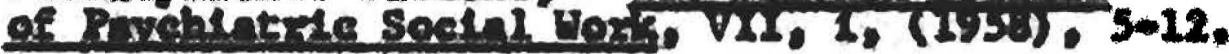

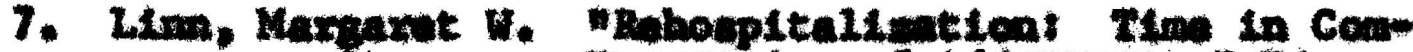

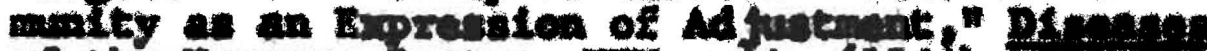

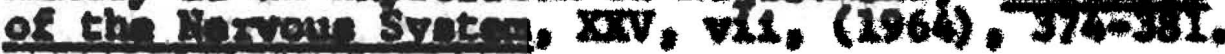

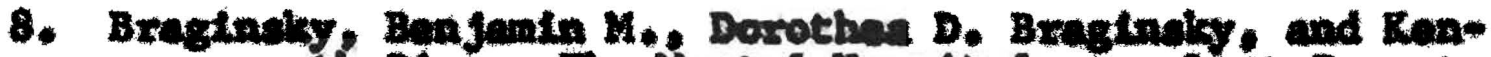

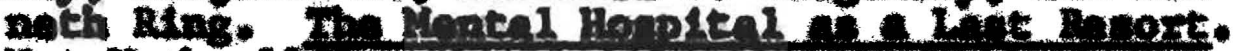
De. Xoxi, $296 \%$

9. Angriet. Shtrley S.. Maris Lefton, Stmon Dinits, and

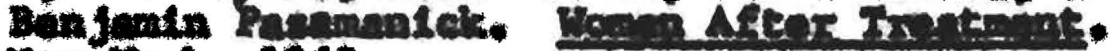
New Yoxk, 1968.

10. Polledk, Max, Staby Lovenoteln, and Deneld F. KLin.

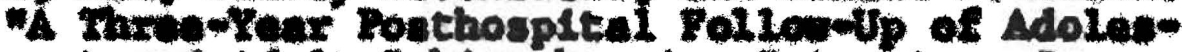

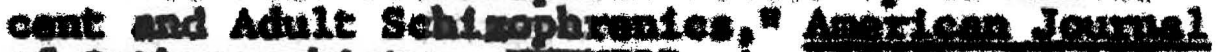

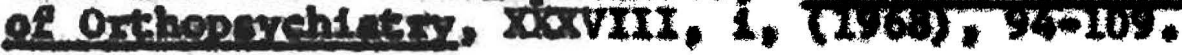

12. Taylox, Robert L. and $\mathrm{E}$. Duller Tormy. Kantel Hanth

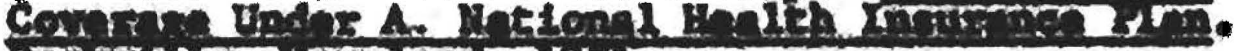

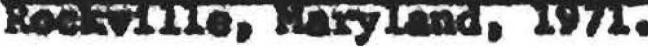




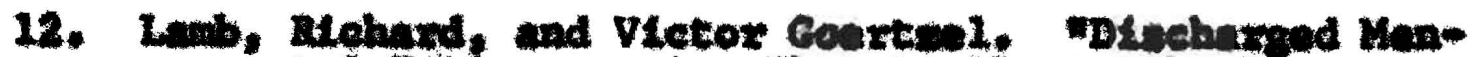
tal tiente - Ax They Beally in the Cennum

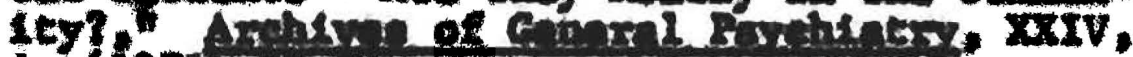
i. (1971) zistis.

13. Maien, Eobert. Whe ExWental Ruttent and Rohospttalletion: Some Recetreh Findinge, " SechI Probirm, $x v, 1,(1967), 18-24$.

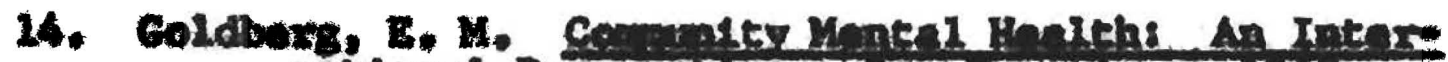

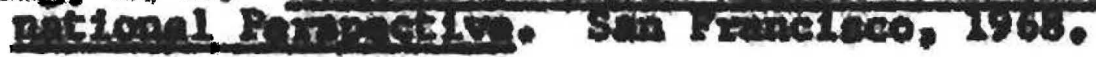

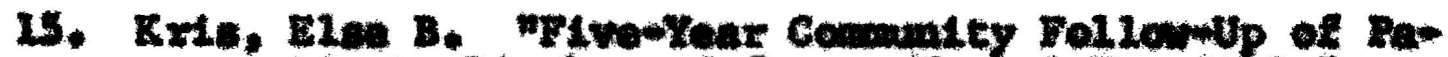

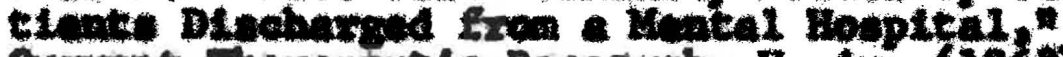
Q.7. abreror.

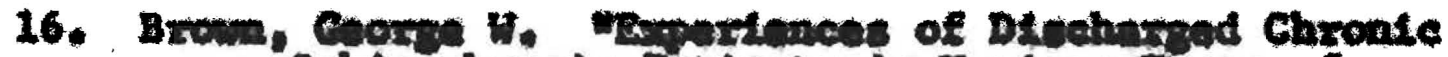

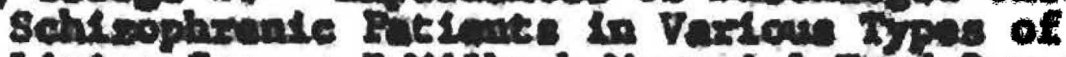

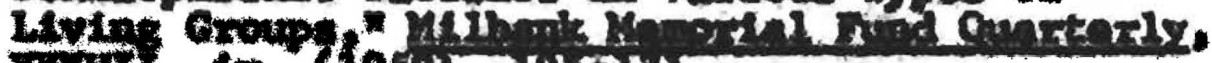
savi, iv, (195i), Lubalsi.

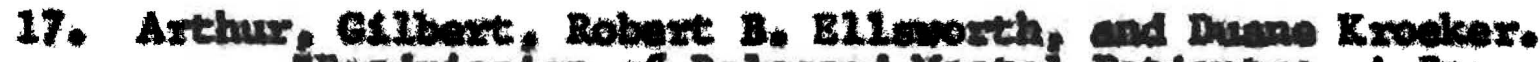

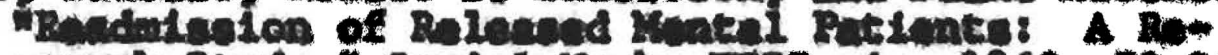

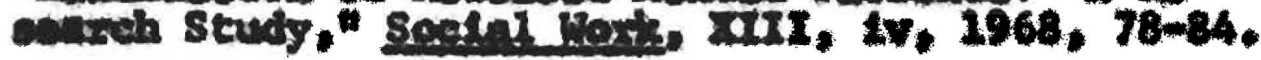

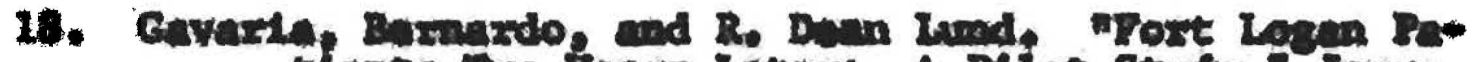

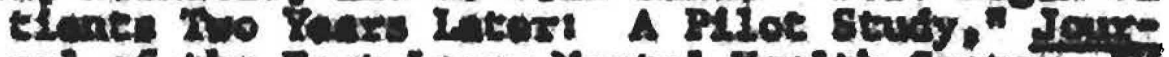

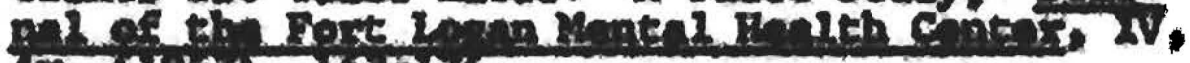
10. (1967), 2635276.

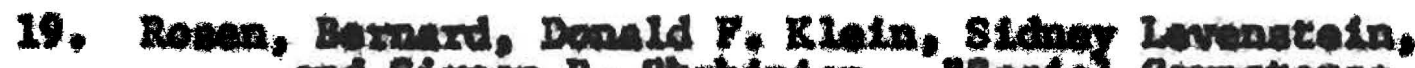

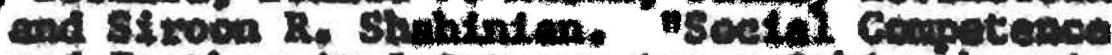

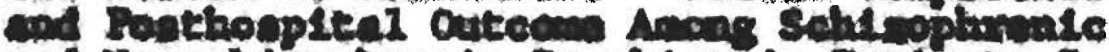

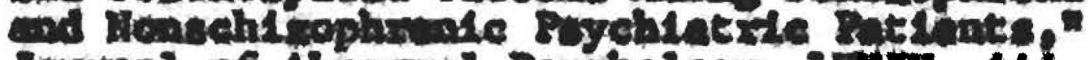

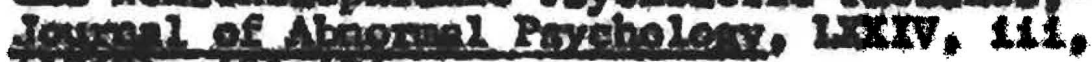
(I)

20. Angrint, Shirley, Stmen Dinite, Maxk Lutton, and Dap:

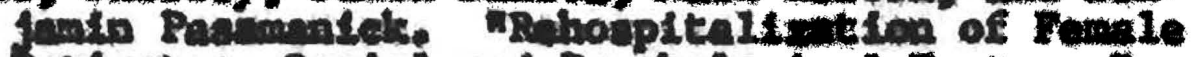

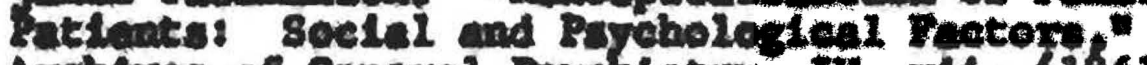

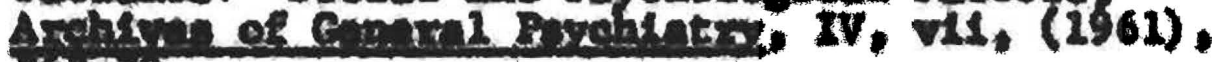
$3630 \%$

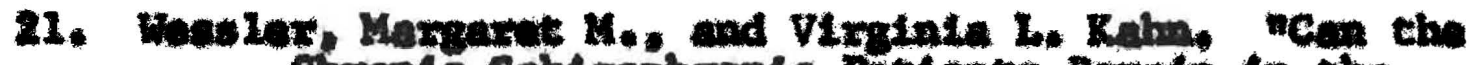

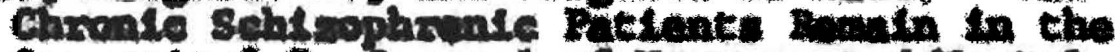

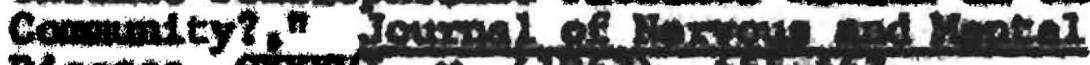

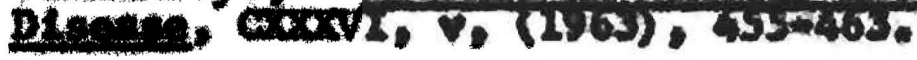


22. Levon, Howand I, VIxinla Patterion, Bxadford Har.

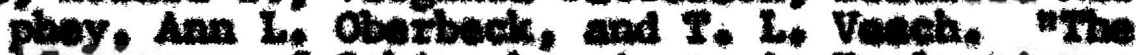

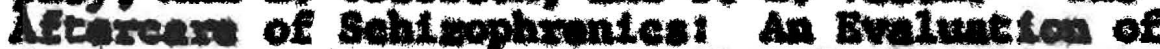

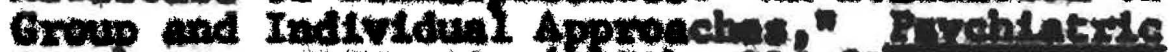

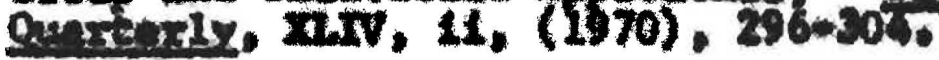

23. Hemalngex, Kaxl, Maxtin Mayman, and Peal Pruyeer,

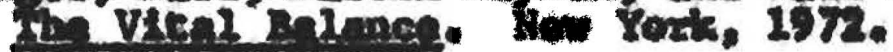

24. Colenen, Jules $V$, A Commatty Frojeet for the Co-

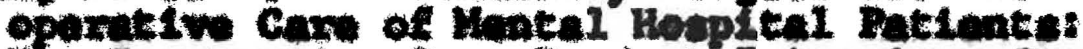

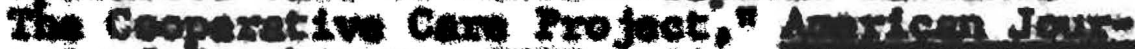

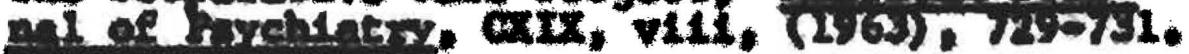

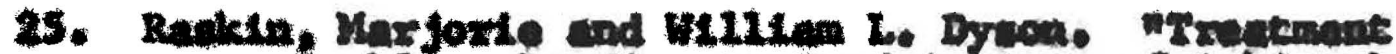

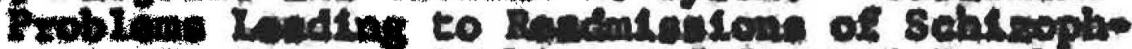

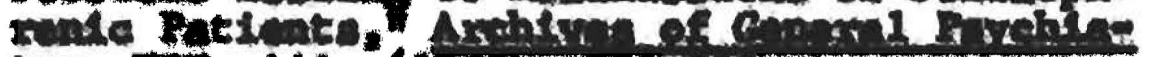

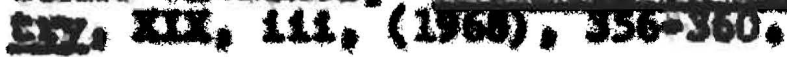

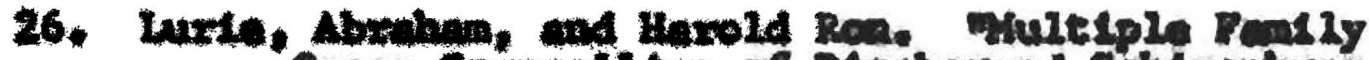

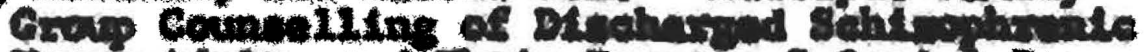

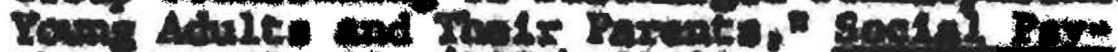
entrat, VI, II, (2971) $85-22$.

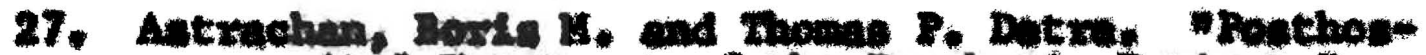

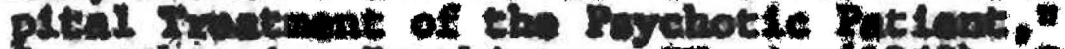

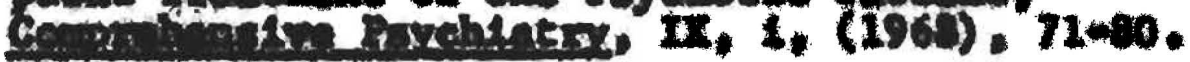

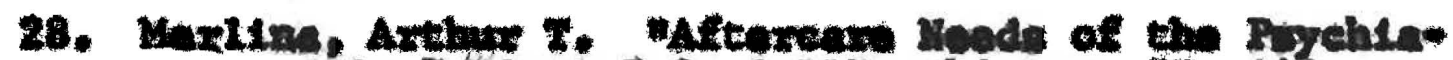

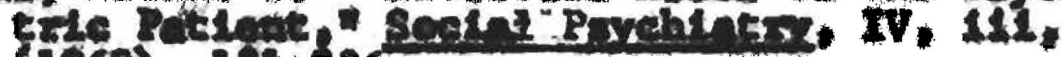
(166). $1213-236$.

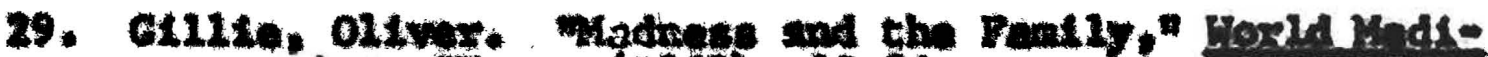
of $, \mathrm{W}, \mathrm{x},(106), 35-36$.

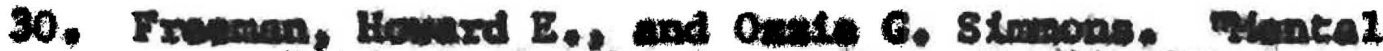

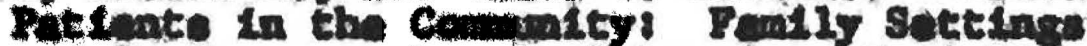

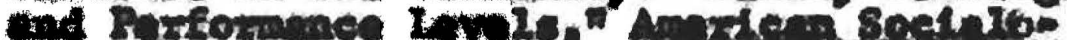

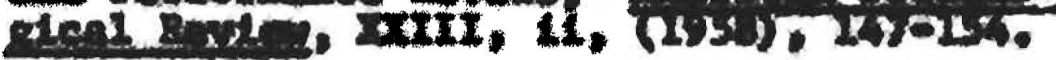

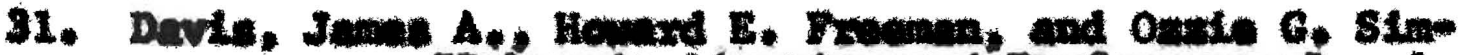

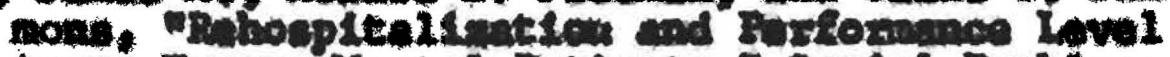

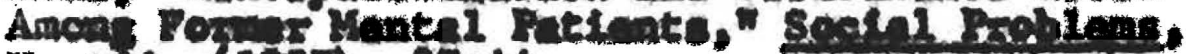
v. vis, (IS5), 37m4.

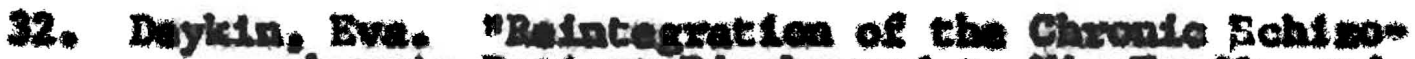
phronie Ratient Discharyed to Ho Fonly and

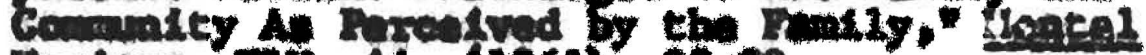

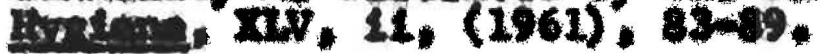




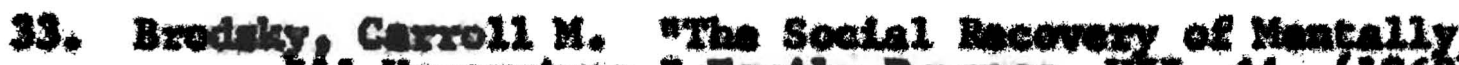

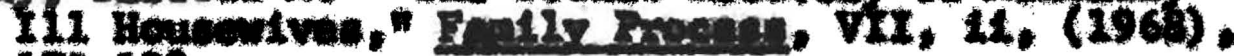
170-183.

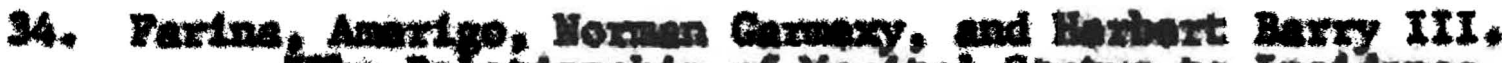

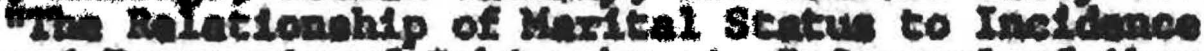

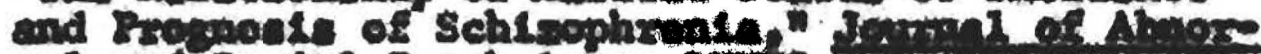

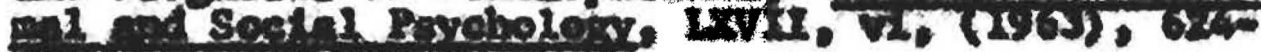
63os

35. Srole, 10o. Hectel Integration and Certain Cozol-

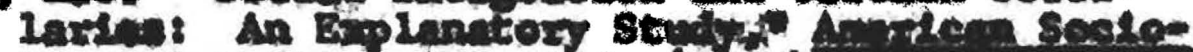

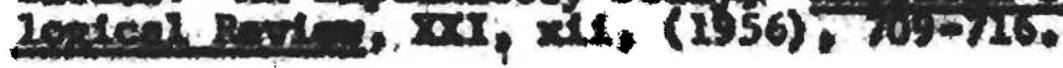

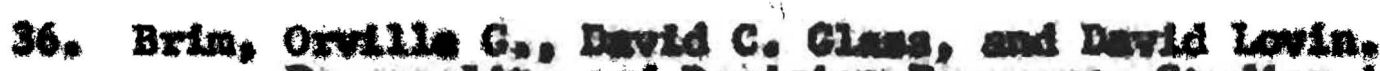

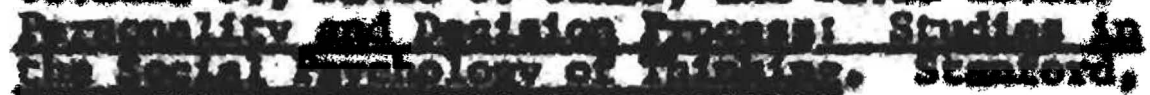
watromat Los.

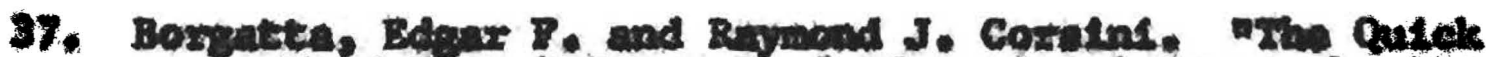

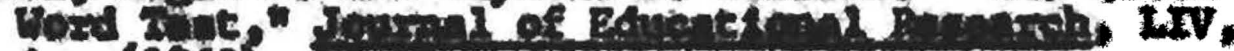
15. (1060), was.

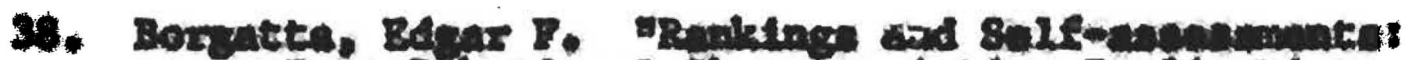

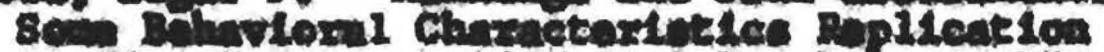

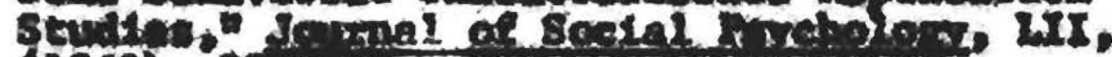
$(200) .27,0.7 \%$

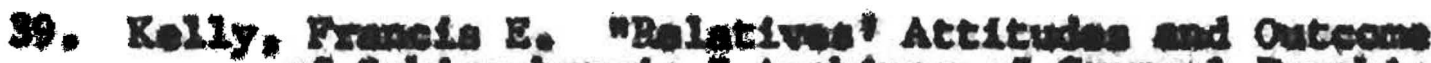

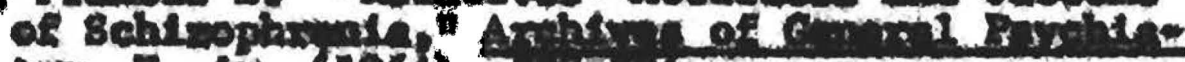

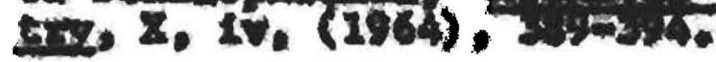

